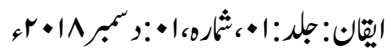

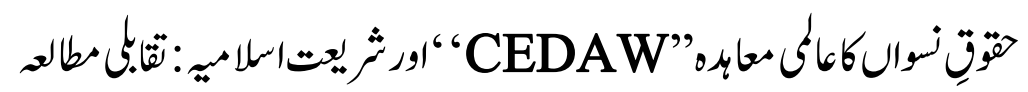

\title{
A Comparative Study of International Treaty for Women Rights \\ "CEDAW" and Islamic Shariah
}

\author{
Sarfraz Hussain Saeed \\ PhD. Scholar, Department of Islamic Studies, \\ University of Gujrat, Gujrat. \\ Shagufta Naveed \\ PhD. Scholar, Department of Islamic Studies, \\ GIFT University, Gujranwala.
}

\begin{abstract}
Women are confronted with a lot of problems. In different parts of the world, some social and cultural attitudes still discourage the women from getting their established and assigned rights. The factors which are responsible for this phenomenon include societal norms, orthodoxy and some social customs contrary to islamic instructions. For instance, discrimination against women could be in terms of inadequate nutrition, denial or limited access to education, health and property rights, child labor, domestic violence and forceful marriage. So far as the Islamic instructions are concerned, these are derived from Quran and Sunnah and clearly describe women's rights but, due to some socio-religious customs and undesirable behaviors the societal status and role of women have been badly affected. An international document, the convention on the elimination of all forms of discrimination against women also lists the rights of all girls and women. CEDAW recommends that all discriminations against girls and women must be ended. In this paper, the terms have been analyzed in the context of islamic instructions and teachings, in order to provide academic material for bringing positive change in the society.
\end{abstract}

Keywords: CEDAW, gender discrimination, islam, women rights

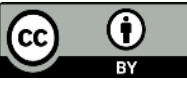




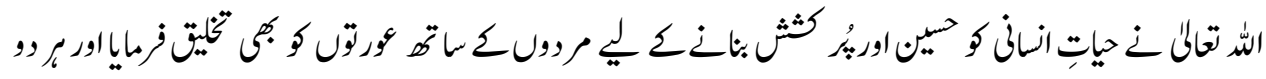

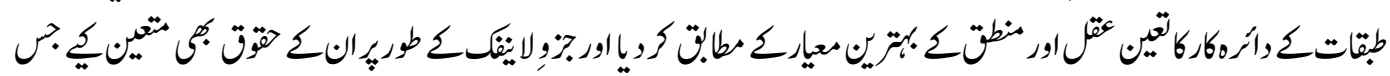

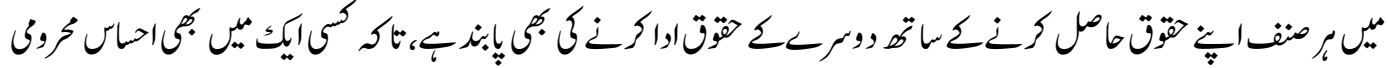

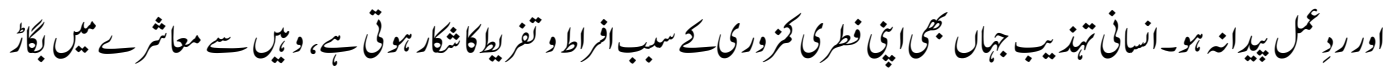

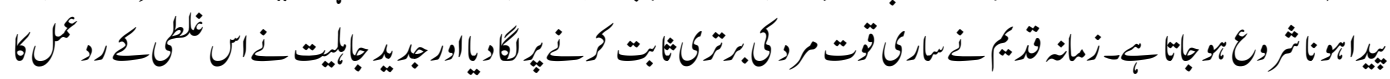

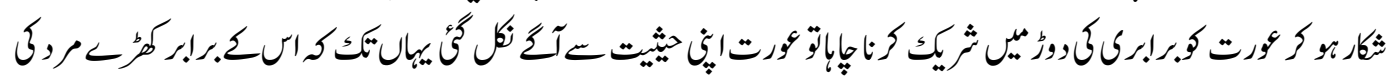

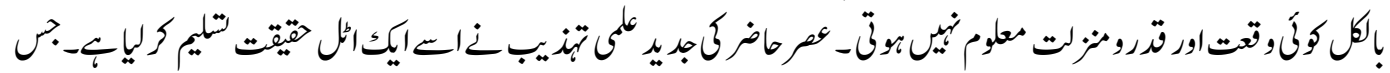

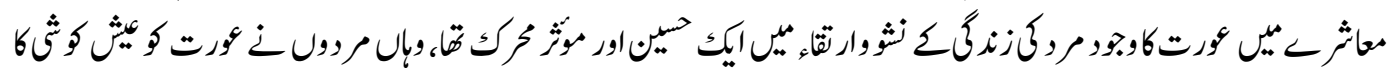

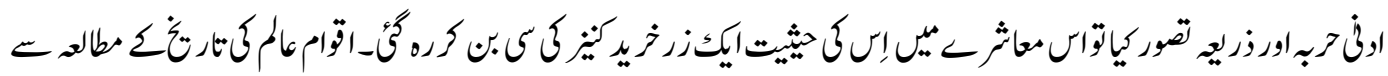

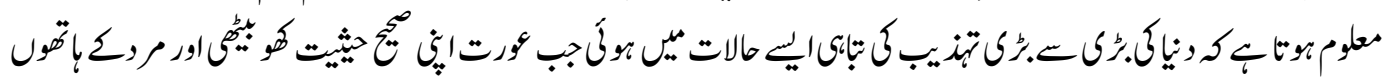

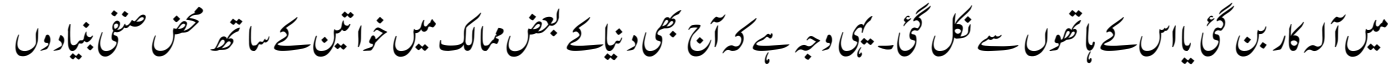

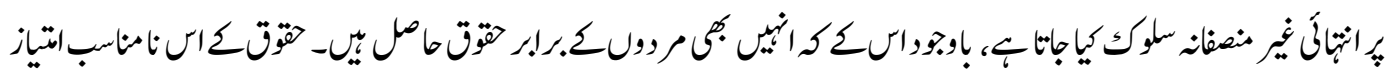

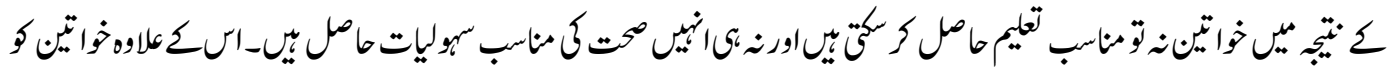

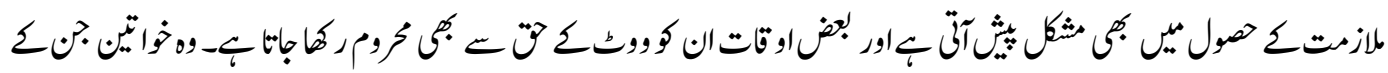

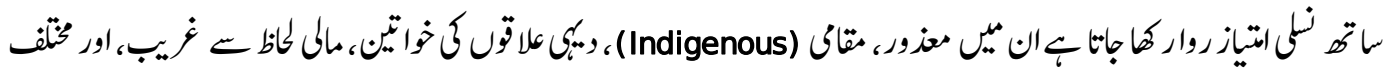

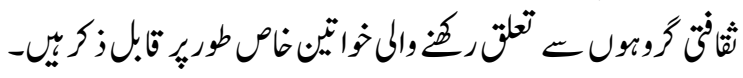

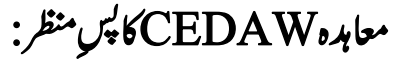

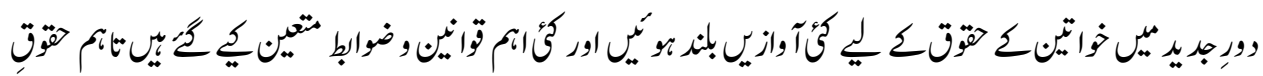

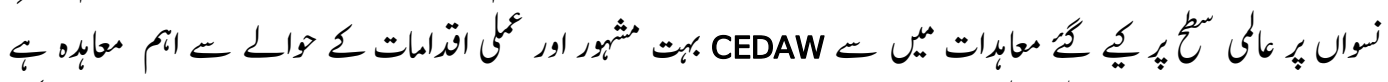

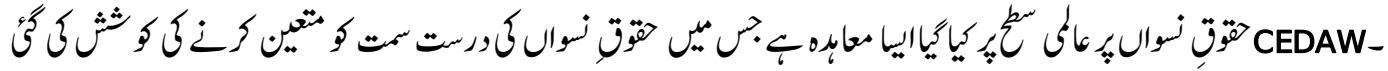
Convention on the Elimination of all forms of انميزى زبان

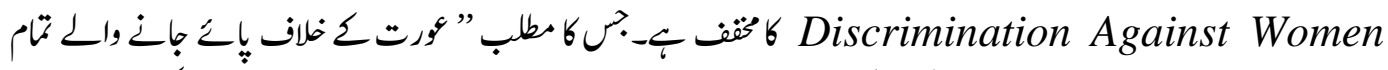

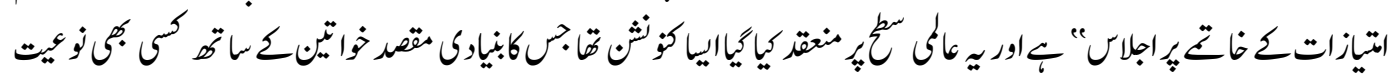

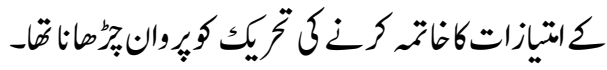


CيDAW

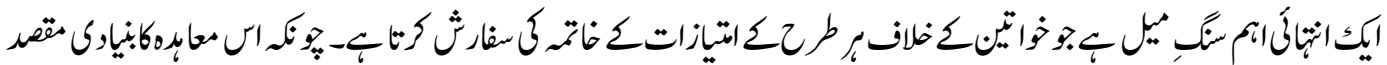

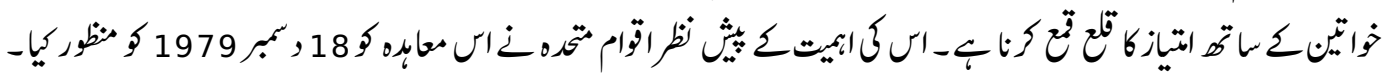

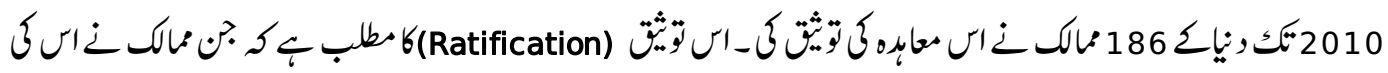

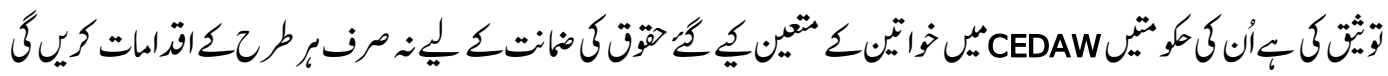

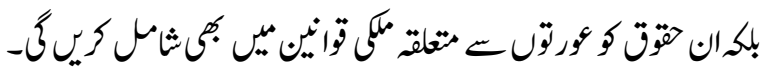

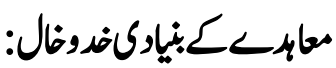

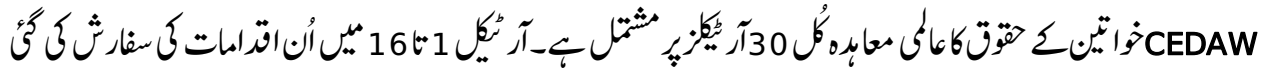

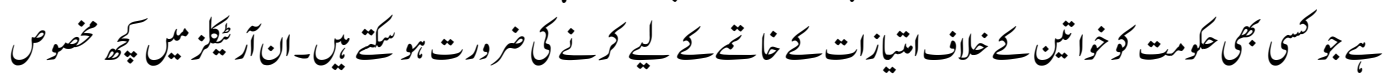

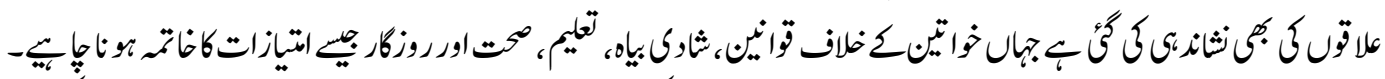

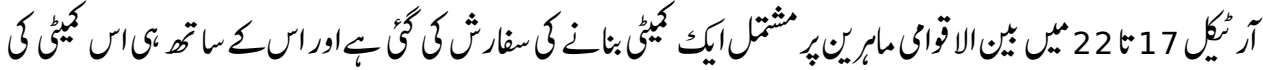

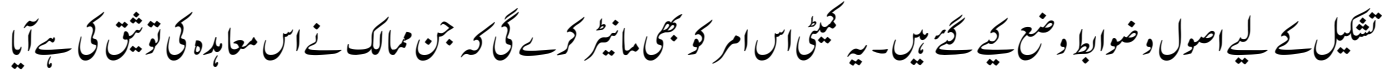

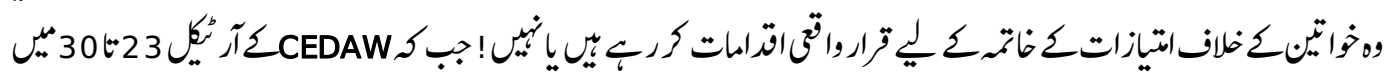

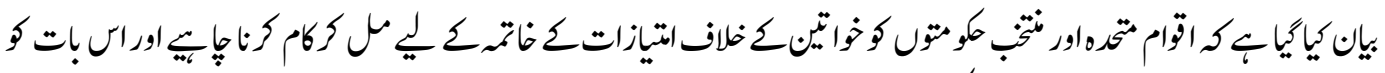

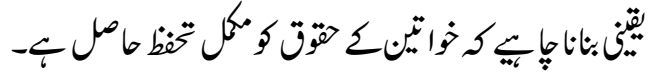

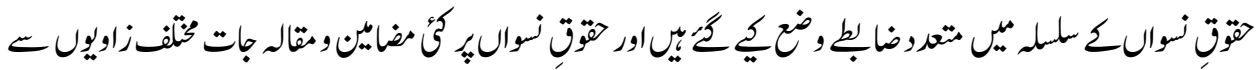

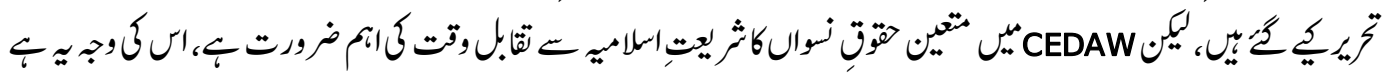

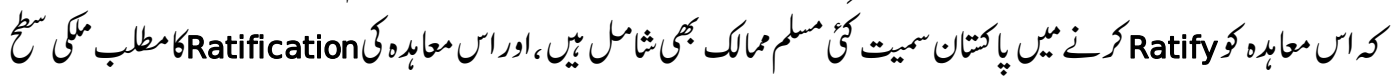

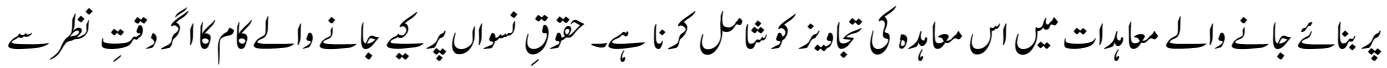

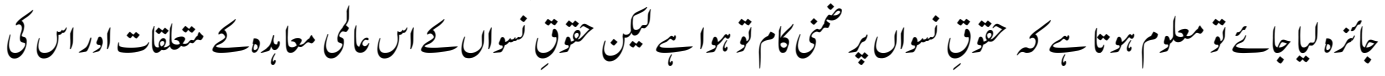

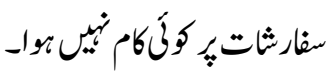

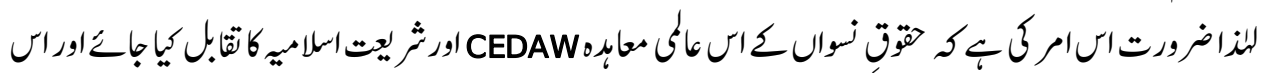

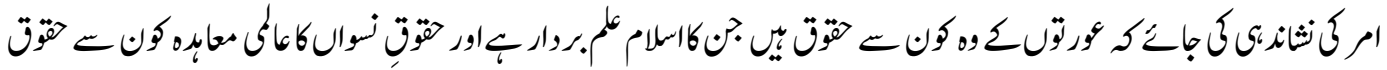

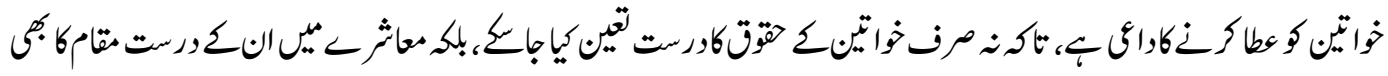

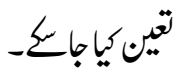




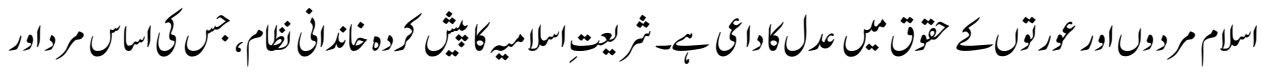

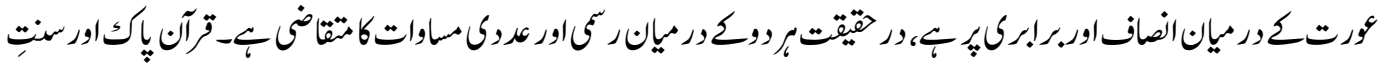

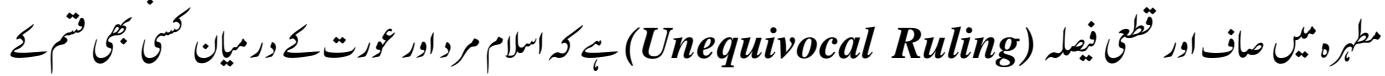

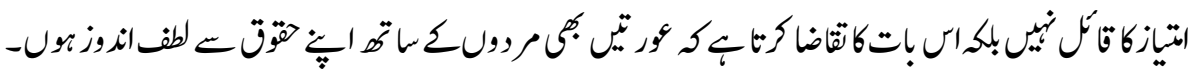

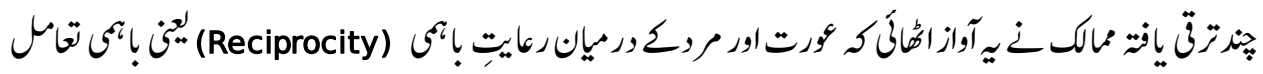

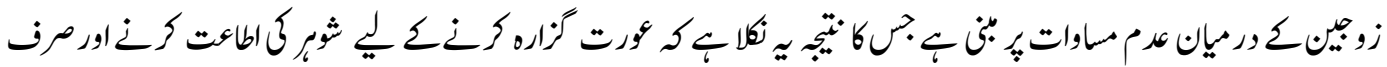

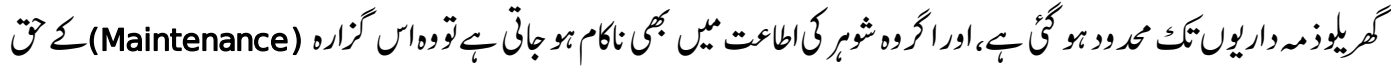

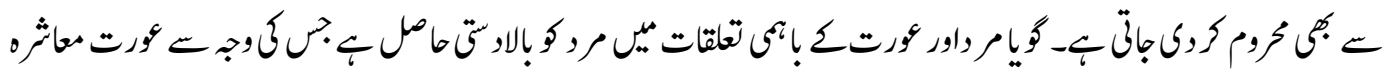

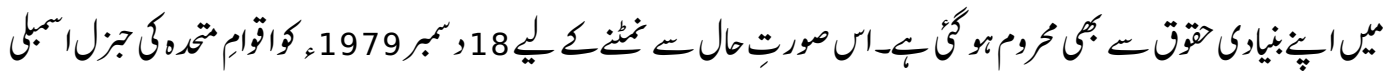

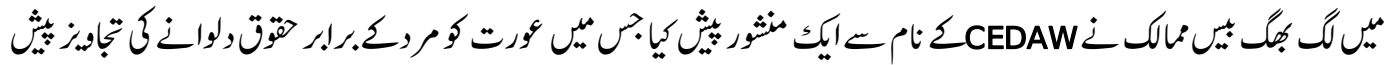

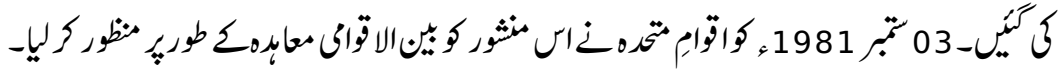

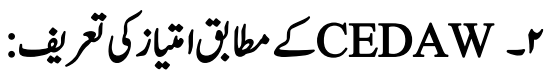

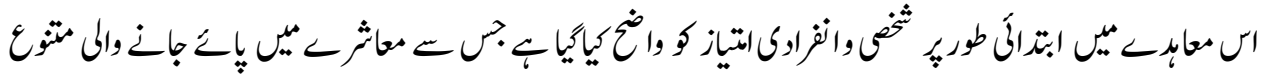

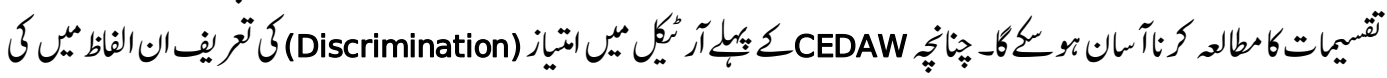

"Discrimination against girls and women means directly or $: 0^{0}$ indirectly treating girls and women differently from boys and men in a way which prevents them from enjoying their rights." ${ }^{1}$

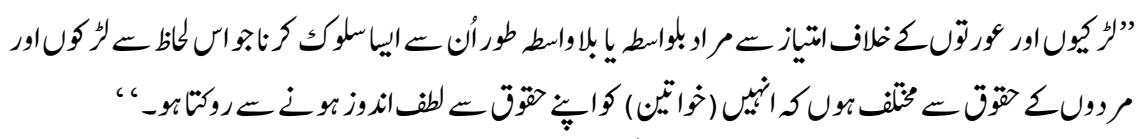

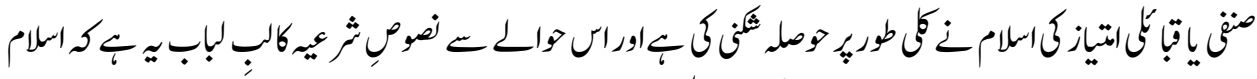

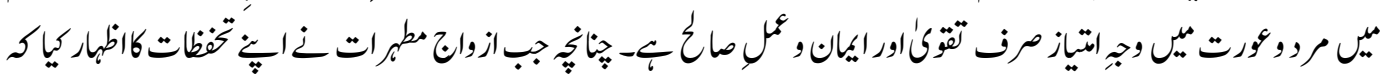

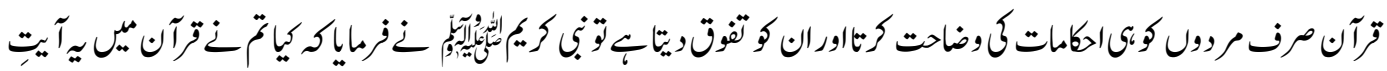

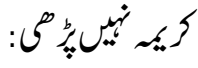

${ }^{1}$ www.un.org/womenwatch/daw/cedaw/text/econvention, (accessed July15, 2018) 


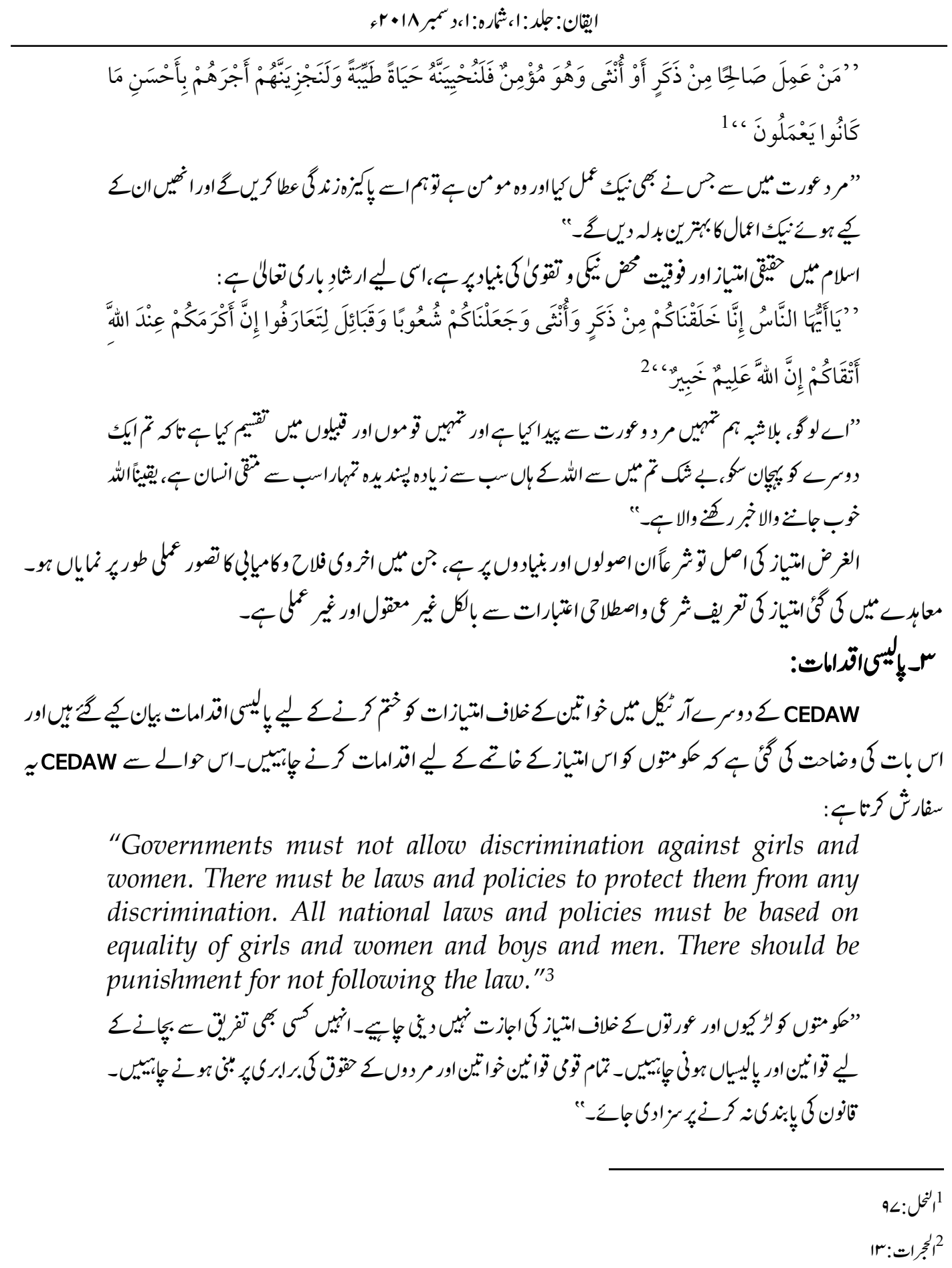

${ }^{3}$ www.un.org/womenwatch/daw/cedaw/text/econvention, (accessed July15, 2018) 


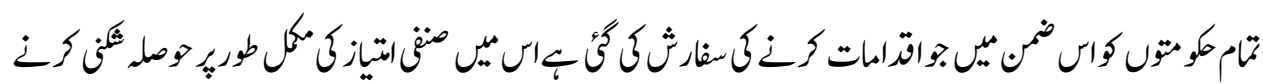

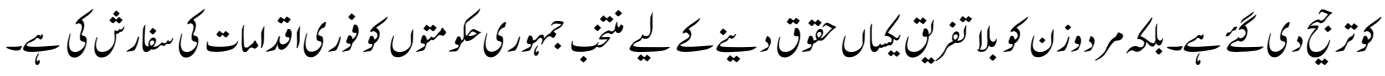

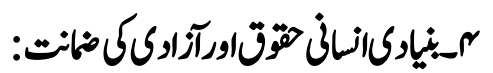

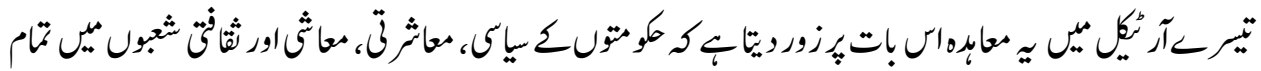

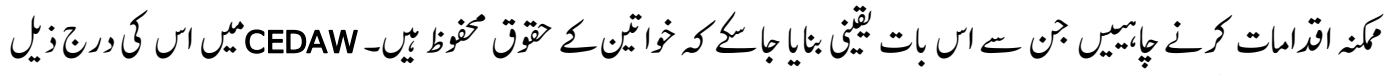

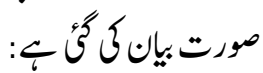

"Governments must take actions in all fields - political, social, economic, and cultural - to ensure girls and women can enjoy basic human rights and freedoms." 1

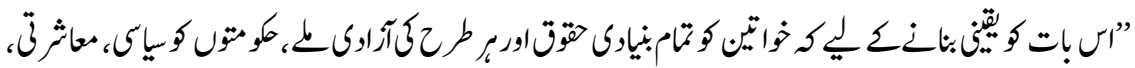

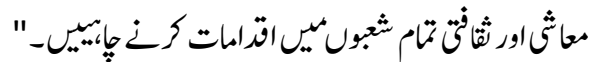

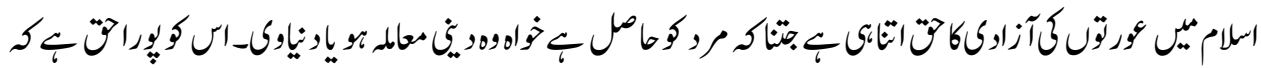

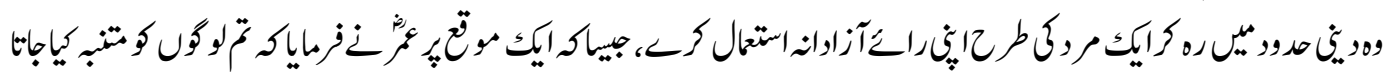

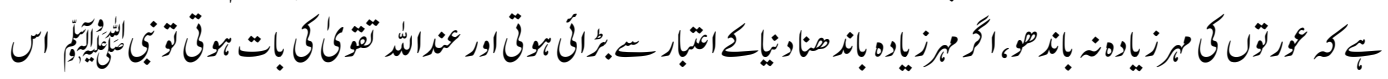

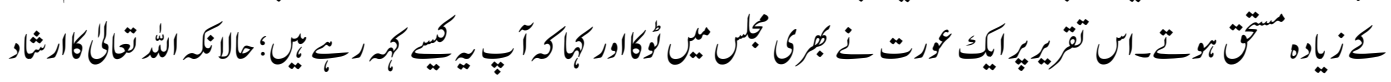

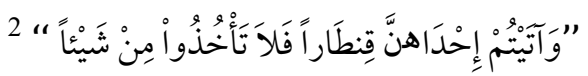

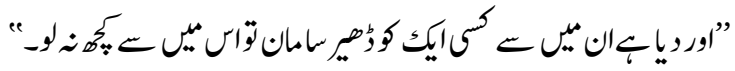

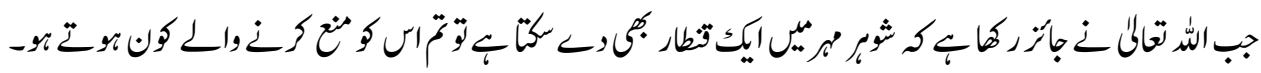

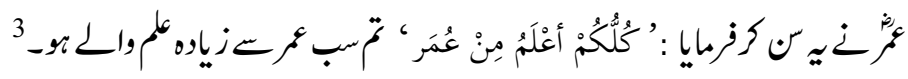

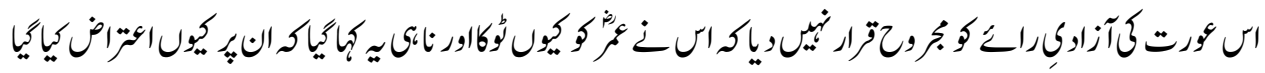

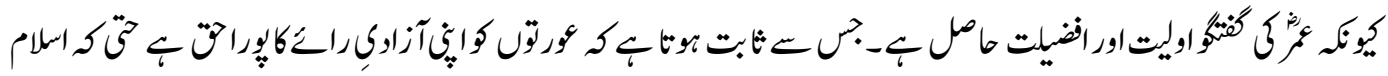

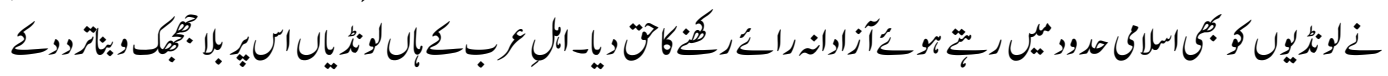

${ }^{1}$ www.un.org/womenwatch/daw/cedaw/text/econvention, (accessed July15, 2018)

$$
r \cdot: \because \operatorname{cis}^{2}
$$

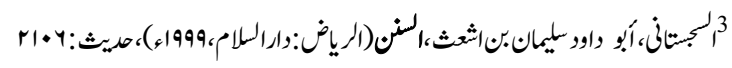




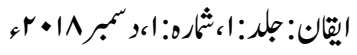

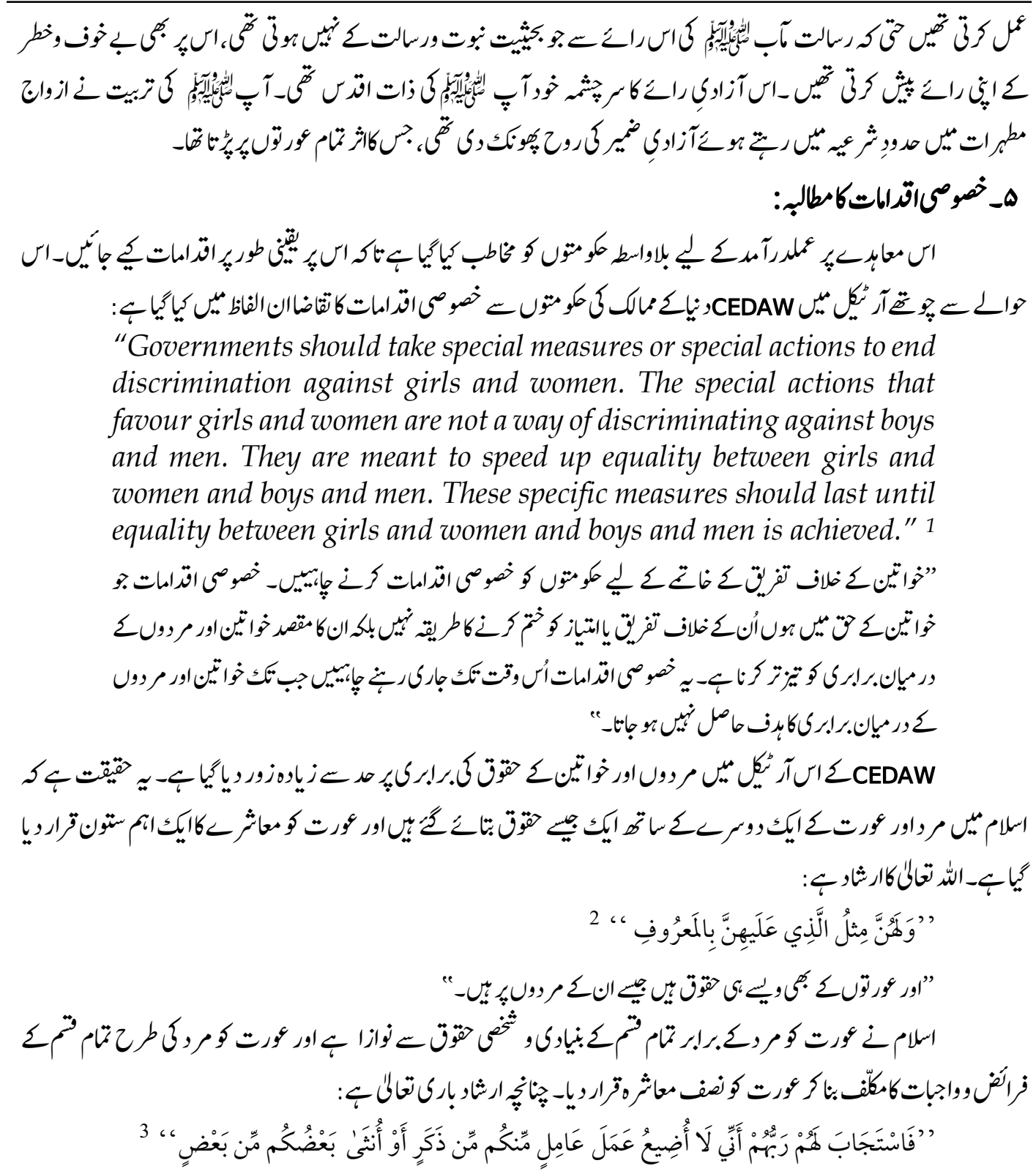

${ }^{1}$ www.un.org/womenwatch/daw/cedaw/text/econvention, (accessed July15, 2018)

$$
\begin{aligned}
& \text { 2 } \\
& \text { 3آ } 1900
\end{aligned}
$$


" "إورت

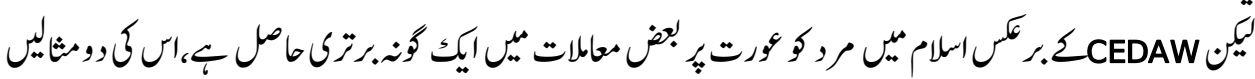

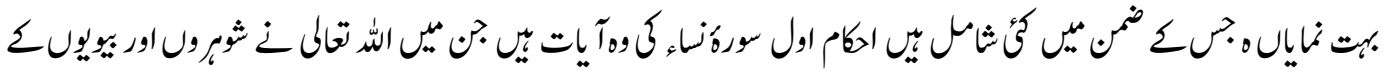

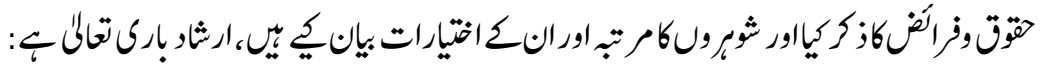

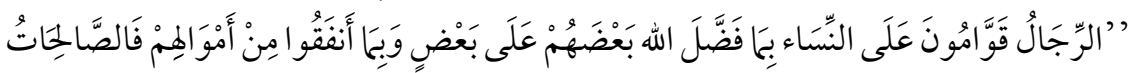

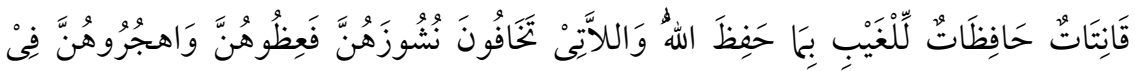

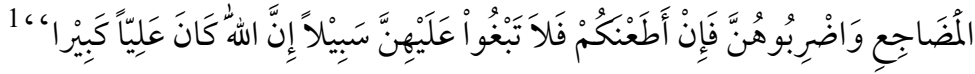

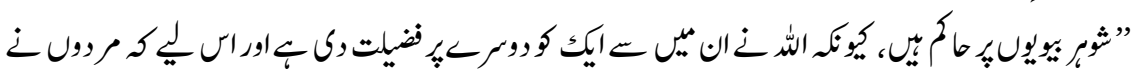

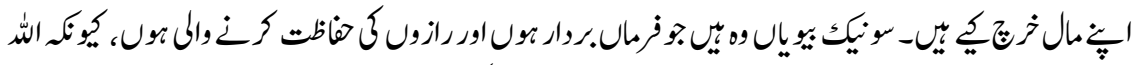

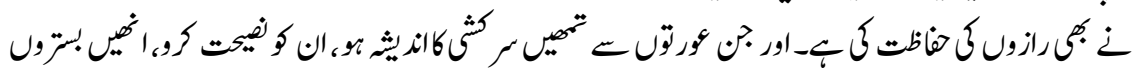

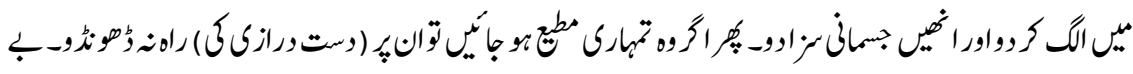

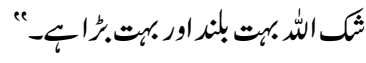

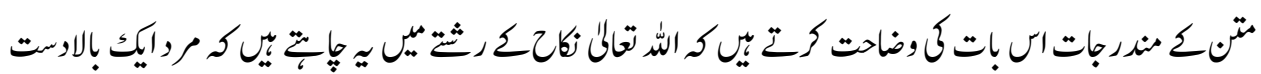

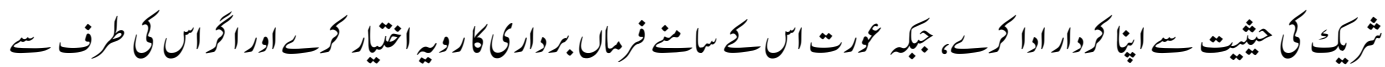

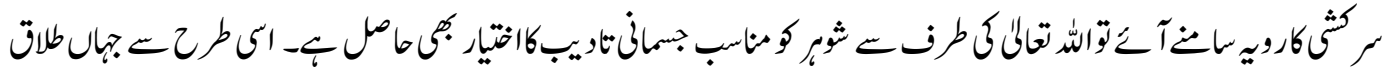

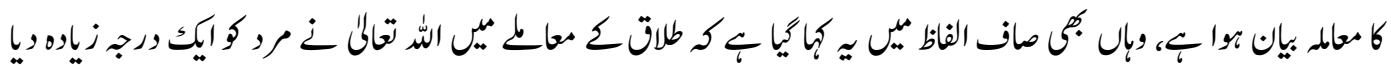

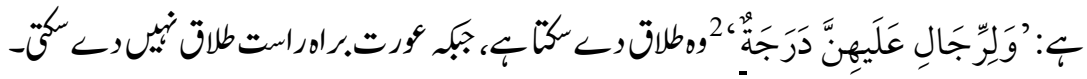

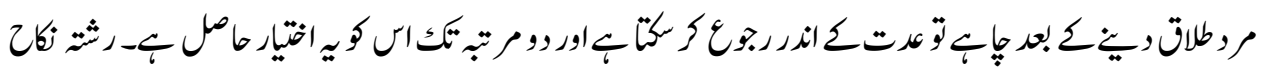

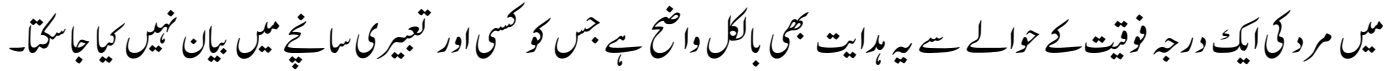

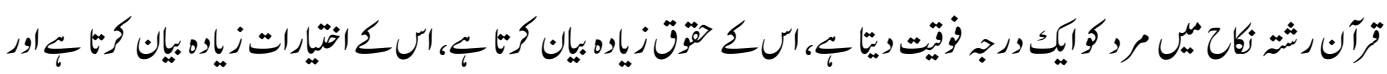

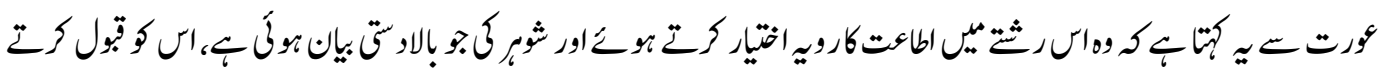
之وبة 


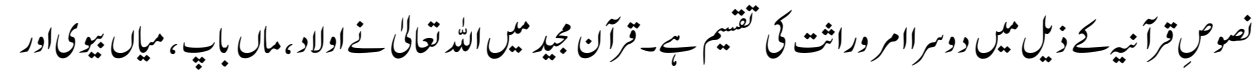

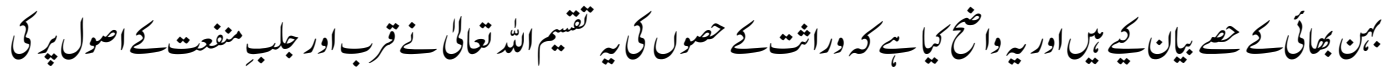

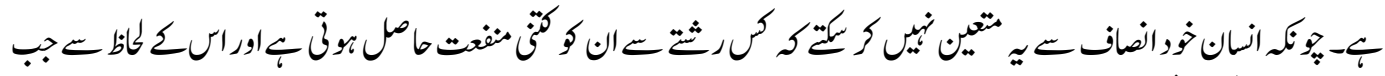

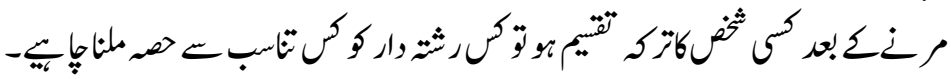

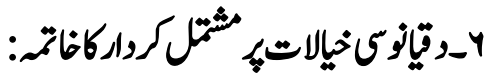

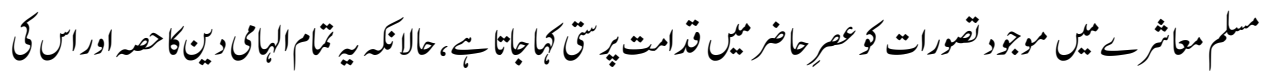

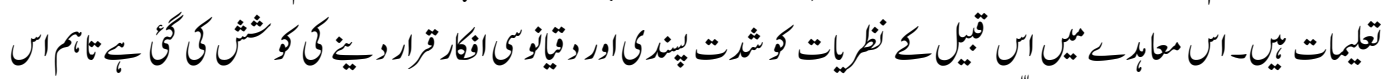

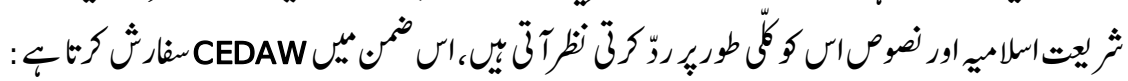
"Governments must work to change stereotypes about girls and women and boys and men, especially if these roles are based on boys and men being considered better than women and girls." 1

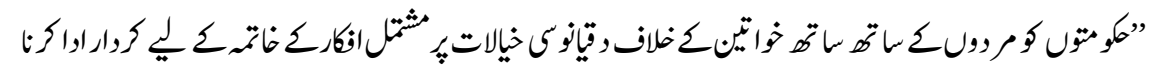

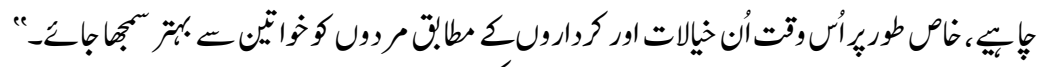

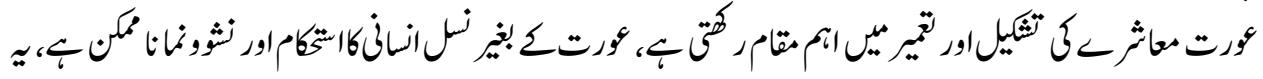

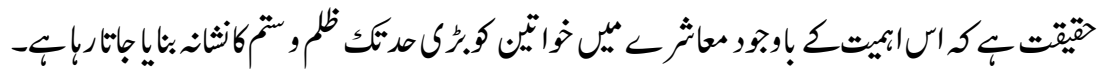
CEDAW

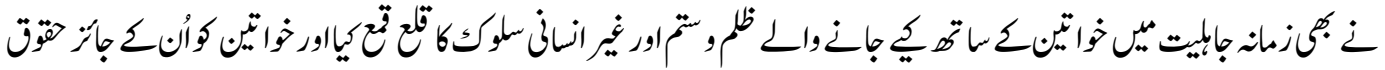

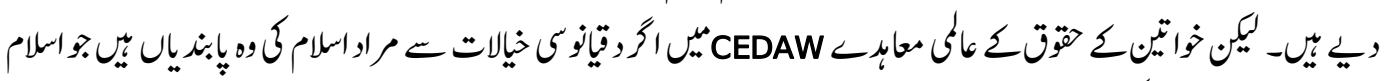

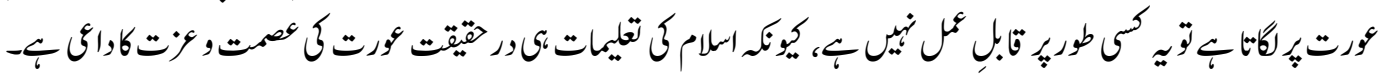

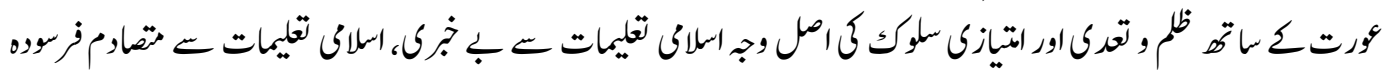

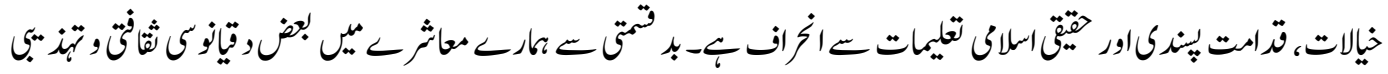

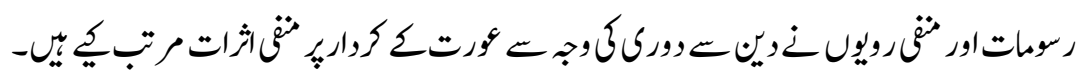

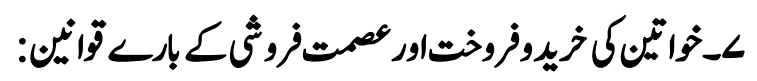

${ }^{1}$ www.un.org/womenwatch/daw/cedaw/text/econvention, (accessed July15,2018) 


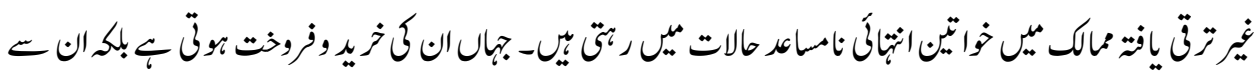

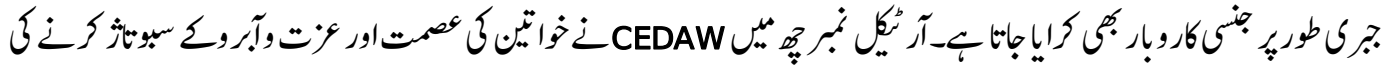
:

"Governments must take action, including making new laws, to end trafficking and prostitution of girls and women."1

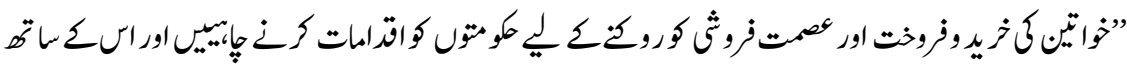

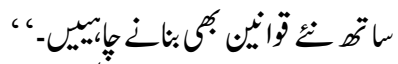

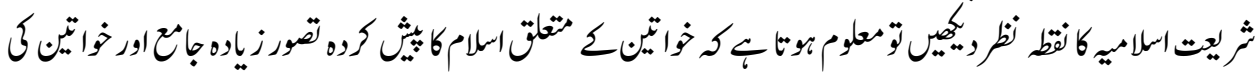

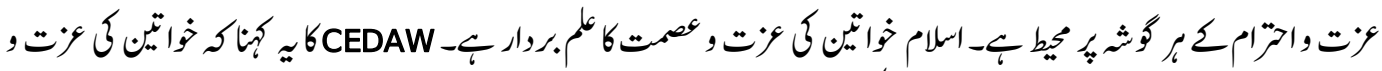

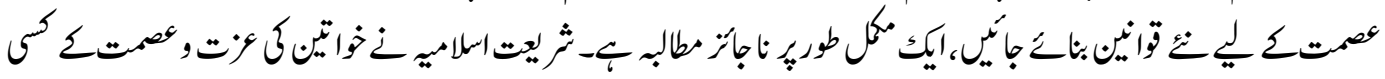

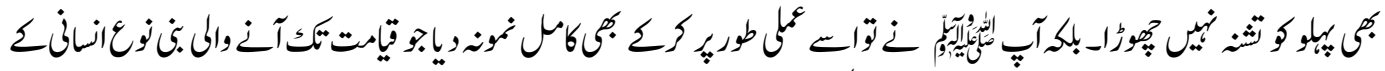

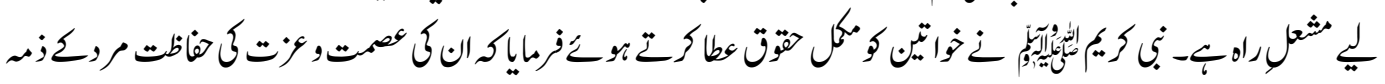

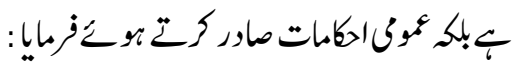

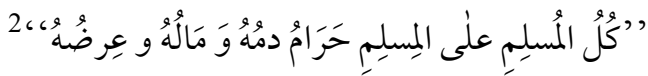

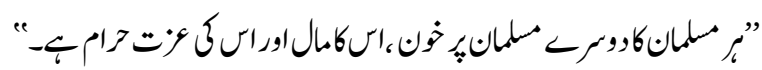

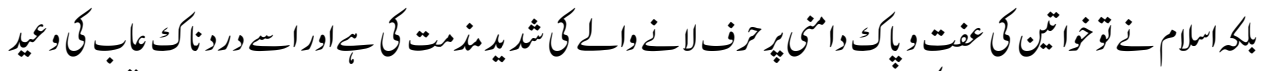

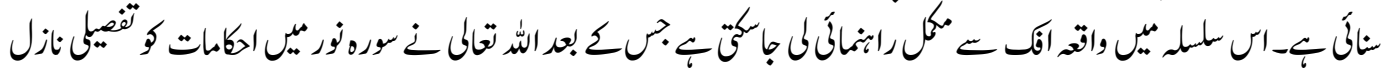

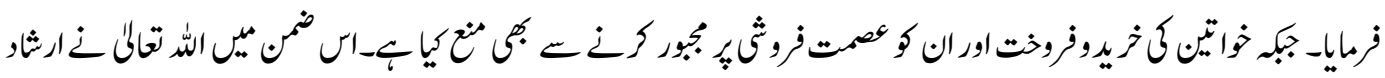

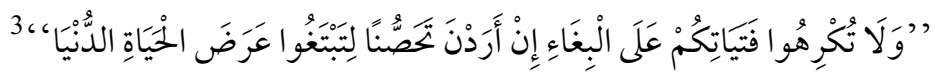

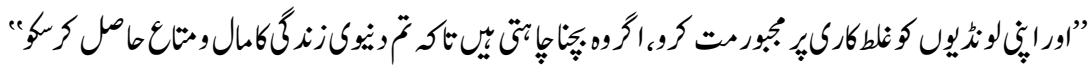

${ }^{1}$ www.un.org/womenwatch/daw/cedaw/text/econvention, (accessed July15, 2018)

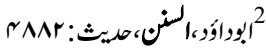

$$
\begin{aligned}
& \text { 3' الثر:مr }
\end{aligned}
$$




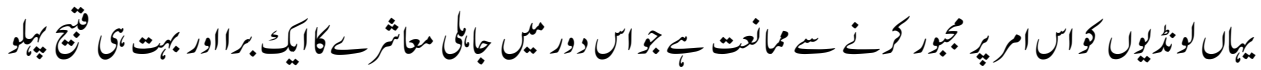

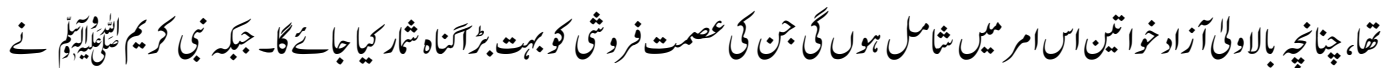

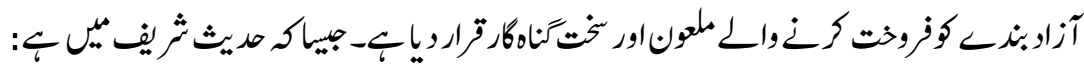

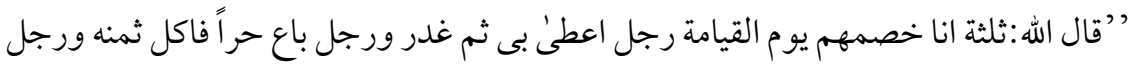

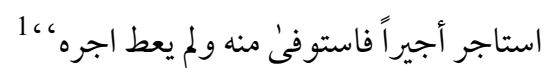

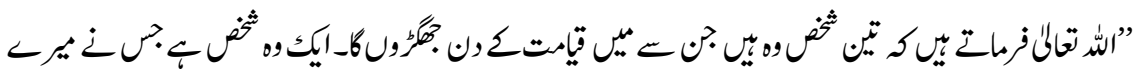

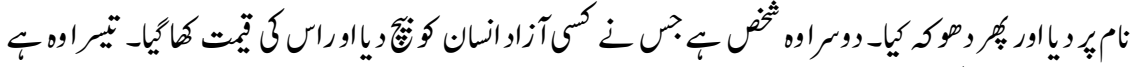

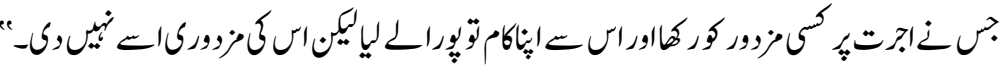

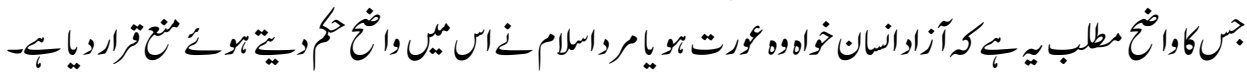

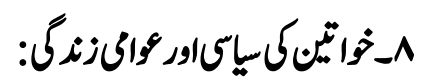
"Women have the same right to vote and be elected to government positions. Girls and women have the right to take part in the decisions a government makes and the way it carries them out. They have the right to participate in non-governmental organizations (NGOs)." 2

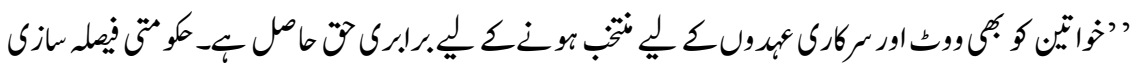

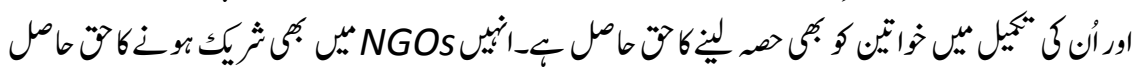

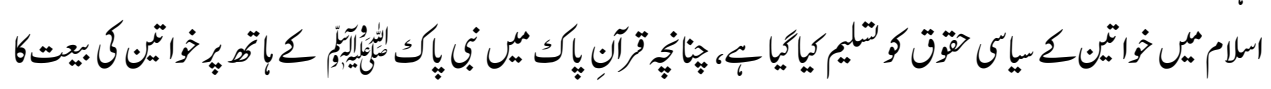

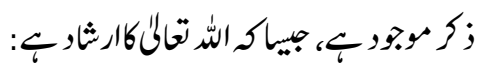

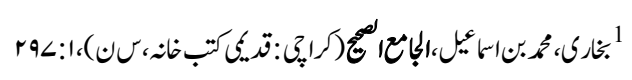

\footnotetext{
${ }^{2}$ www.un.org/womenwatch/daw/cedaw/text/econvention, (accessed July15, 2018)
} 


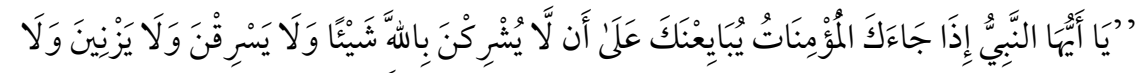

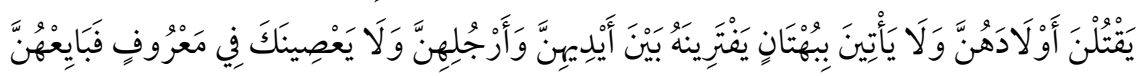

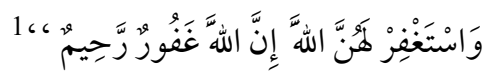

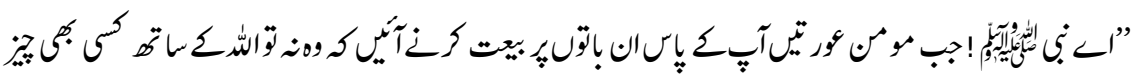

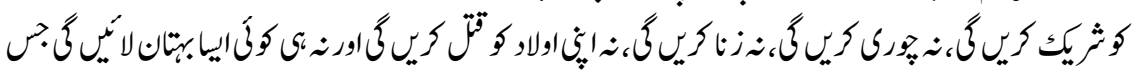

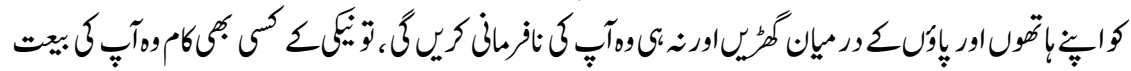

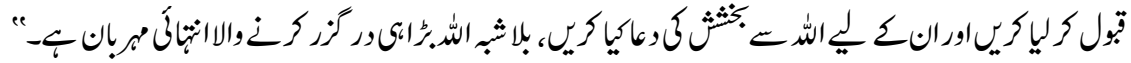

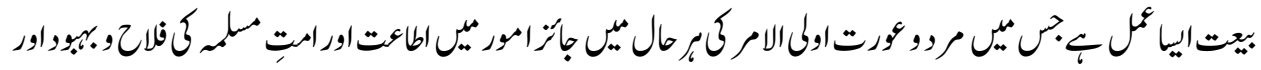

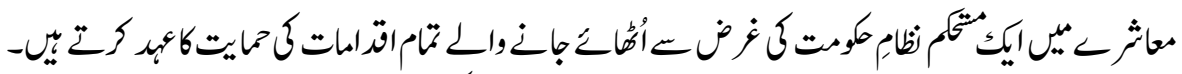

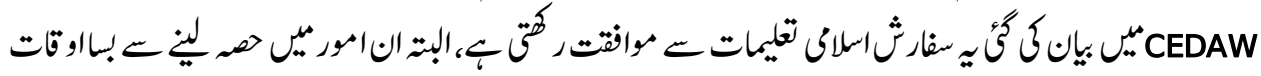

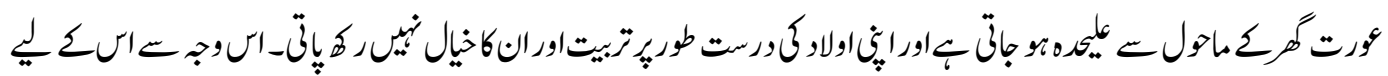

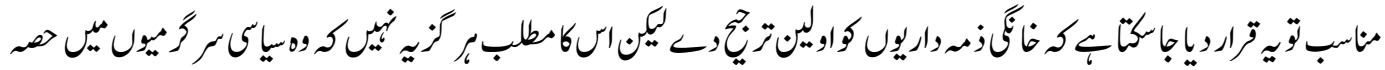

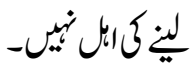

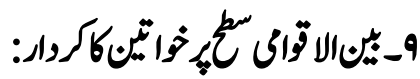

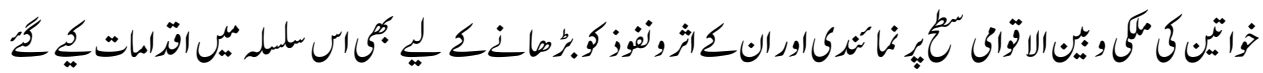

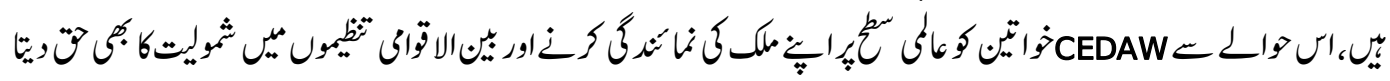

"Girls and women have the right to represent their country at the international level and to participate in the work of international organizations [such as the United Nations, the European Union, and the International Committee of the Red Cross, among many others]."2

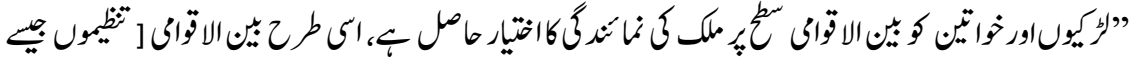

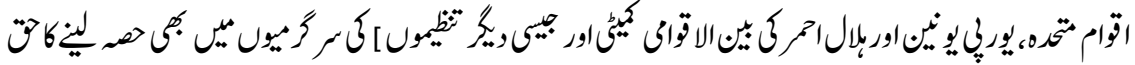

$$
\begin{aligned}
& \text { " } \div \text {. }
\end{aligned}
$$

${ }^{2}$ www.un.org/womenwatch/daw/cedaw/text/econvention, (accessed July15, 2018) 


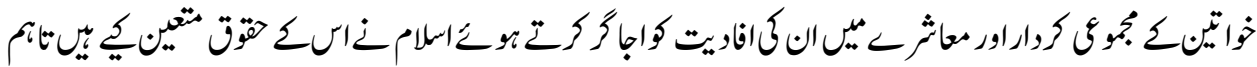

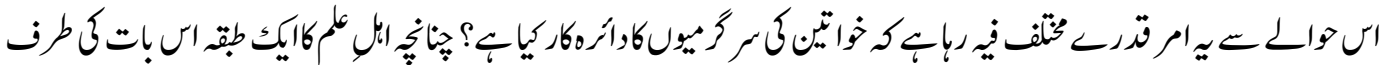

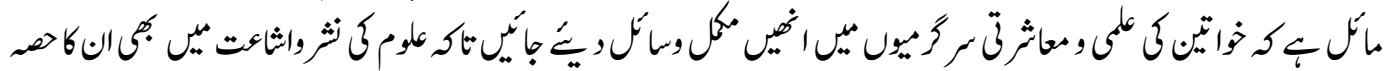

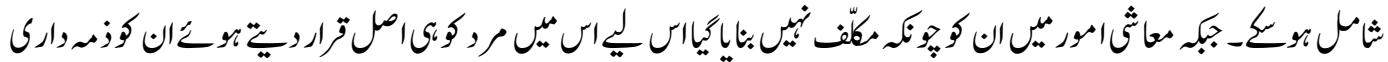

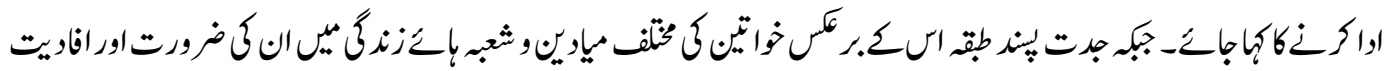

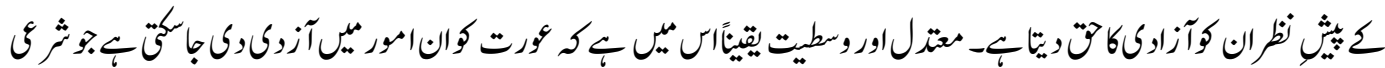

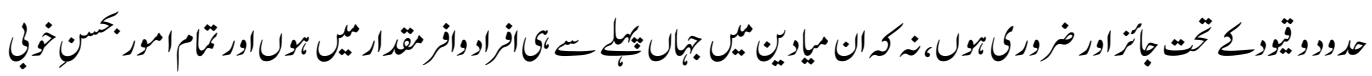

$$
\begin{aligned}
& \text { اواتوركخون }
\end{aligned}
$$

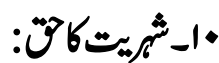

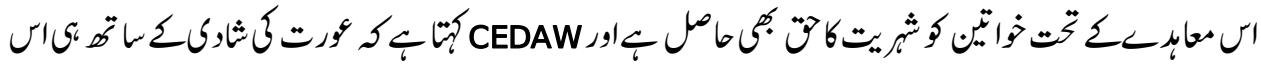

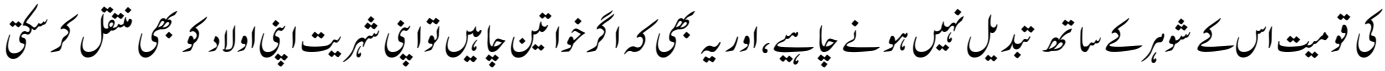

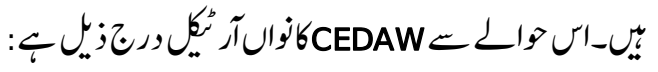

"Girls and women have the right to have a nationality, and to change it if they want. A woman's nationality must not be changed automatically just because she got married, or because her husband changed his nationality. Women can pass on their nationality to their children, the same as men."1

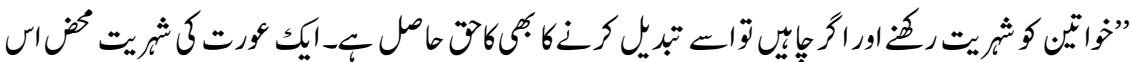

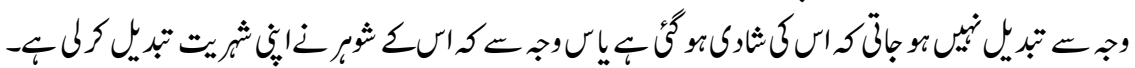

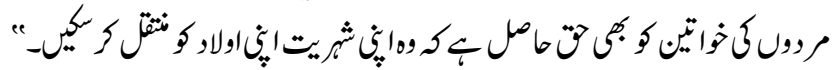

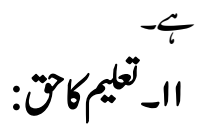

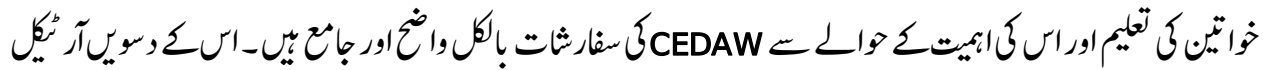

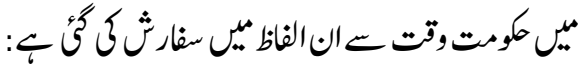

${ }^{1}$ www.un.org/womenwatch/daw/cedaw/text/econvention, (accessed July15, 2018) 


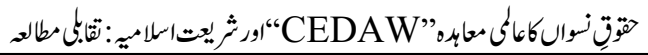

"Governments must end discrimination against girls and women in education. Girls and women have a right to education, just as boys and men do. Girls and women should have access to career guidance and professional training at all levels; to studies and schools; to examinations, teaching staff, school buildings, and equipment; and opportunities to get scholarships and grants, the same as boys and men. Girls and women have the right to take part in sports and physical education, and to get specific information to ensure the health and well-being of families. Governments should make sure girls do not drop out of school. They should also help girls and women who have left school early to return and complete their education."1

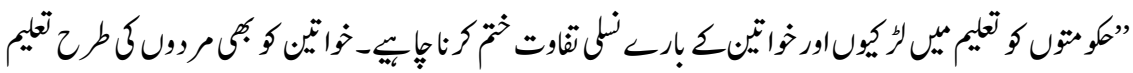

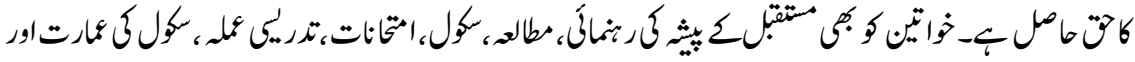

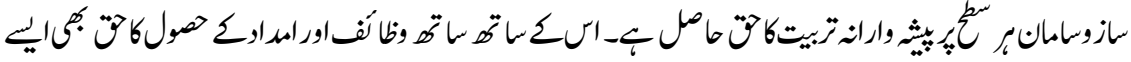

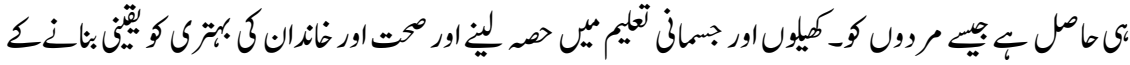

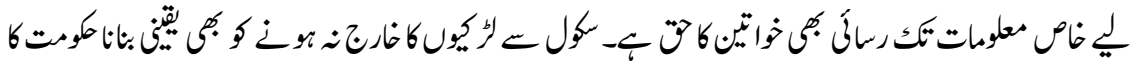

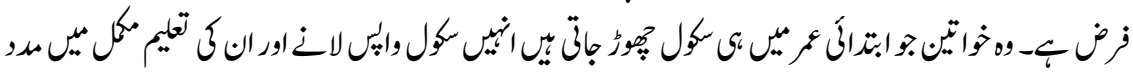

$$
\begin{aligned}
& \text { " }
\end{aligned}
$$

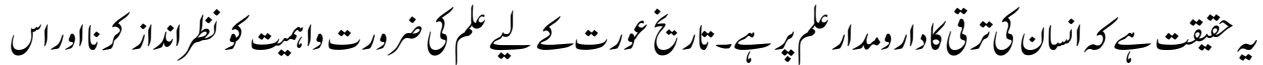

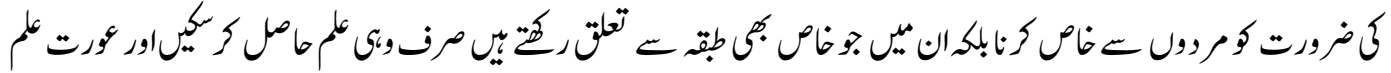

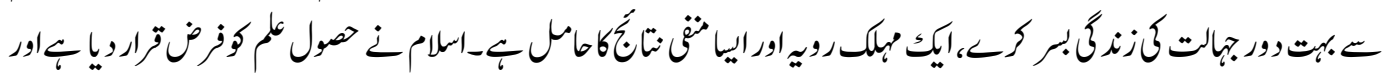

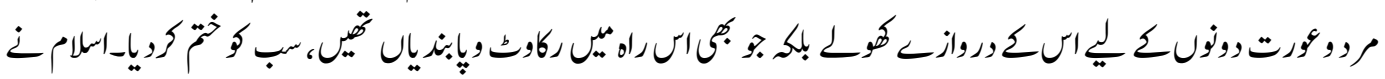

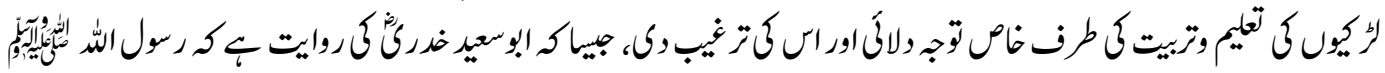

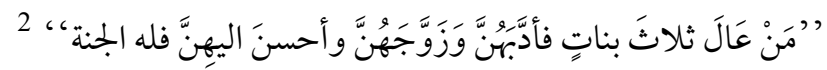

${ }^{1}$ www.un.org/womenwatch/daw/cedaw/text/econvention, (accessed July15, 2018)

$$
\text { 2 }
$$




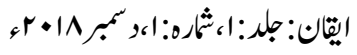

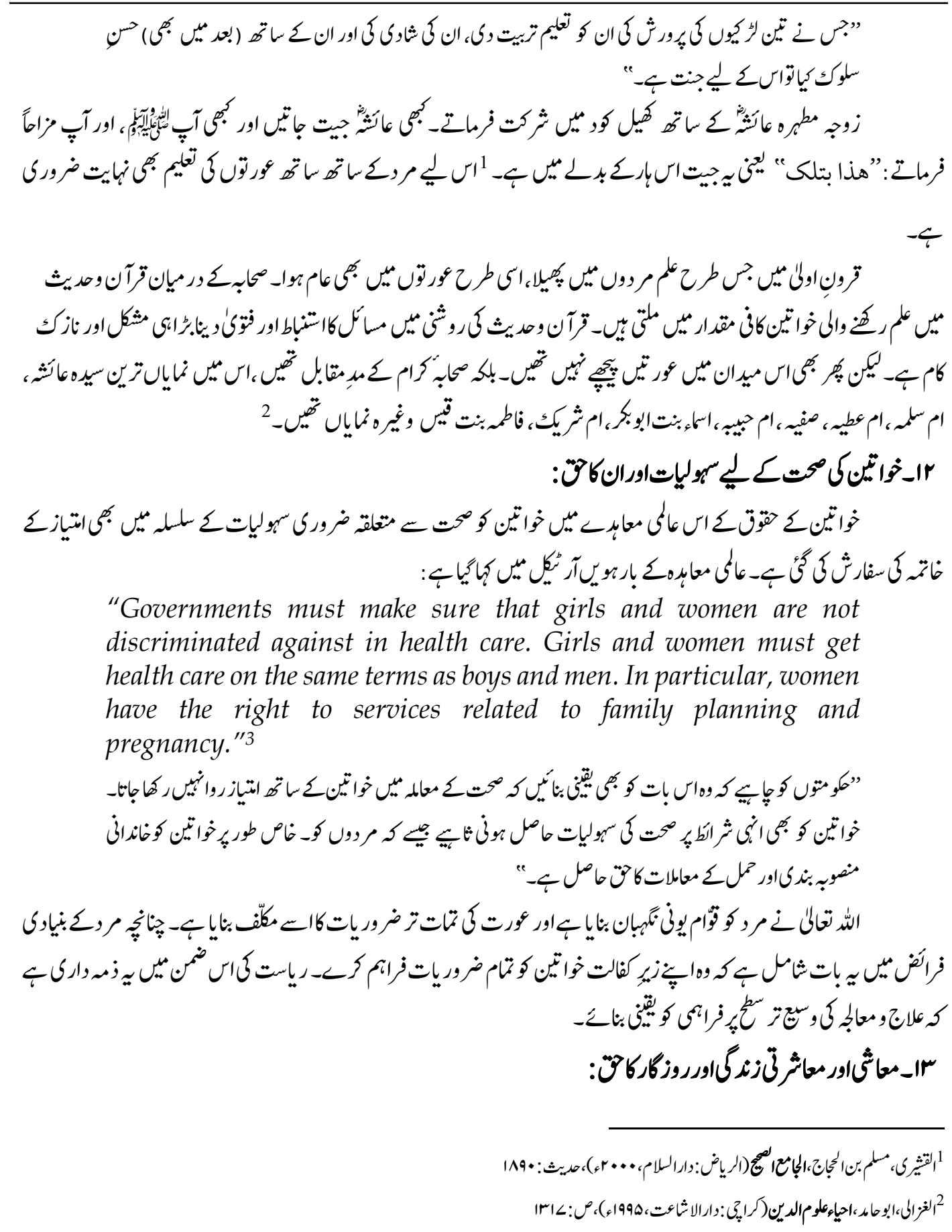

${ }^{3}$ www.un.org/womenwatch/daw/cedaw/text/econvention, (accessed July15, 2018) 


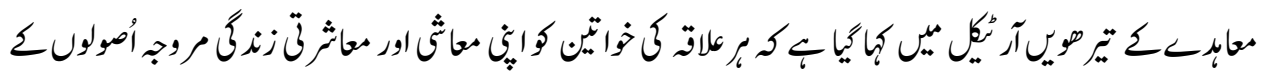

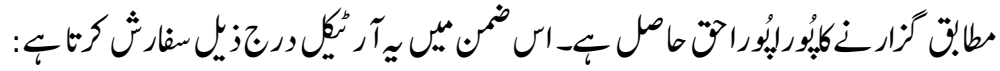

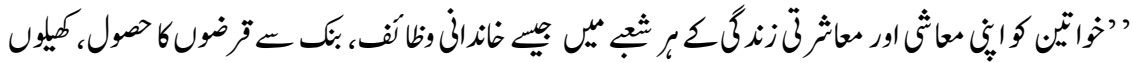

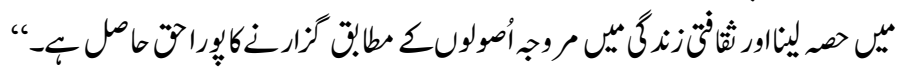

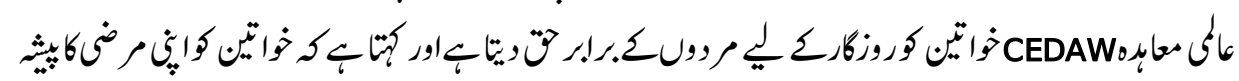

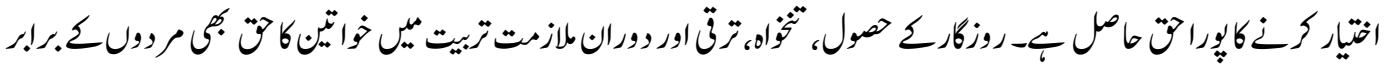

$$
\begin{aligned}
& \text { : }
\end{aligned}
$$

"Women have a right to work just like men. They should be able to join a profession of their choice. Women must have the same chances to find work, get equal pay, promotions and training and have access to healthy and safe working conditions. Women should not be discriminated against because they are married, pregnant, just had a child or are looking after children. Women should get the same assistance from the government for retirement, unemployment, sickness and old age."2

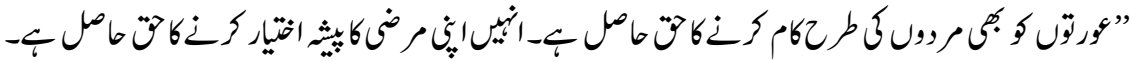

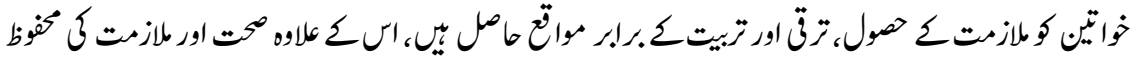

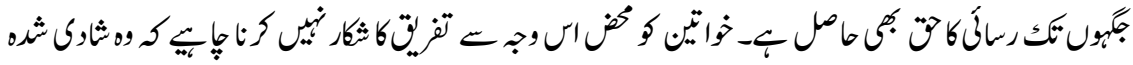

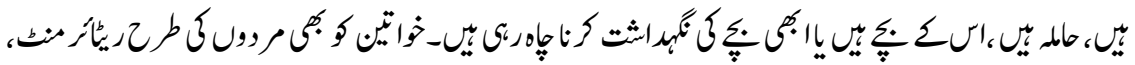

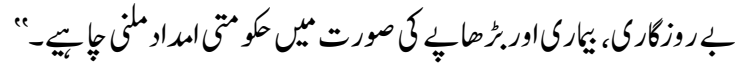

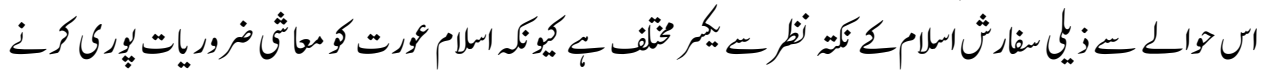

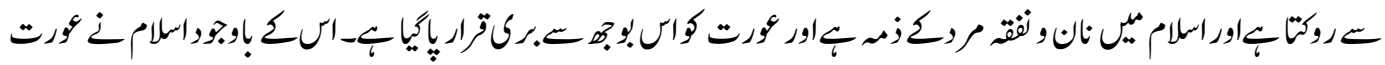

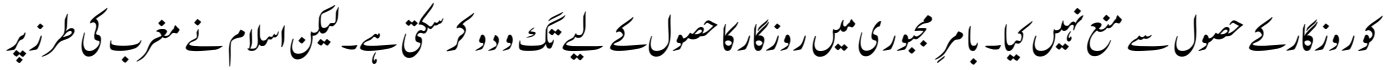

${ }^{1}$ www.un.org/womenwatch/daw/cedaw/text/econvention, (accessed July15, 2018)

2 www.un.org/womenwatch/daw/cedaw/text/econvention, (accessed July15, 2018) 


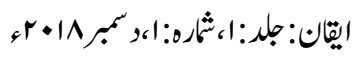

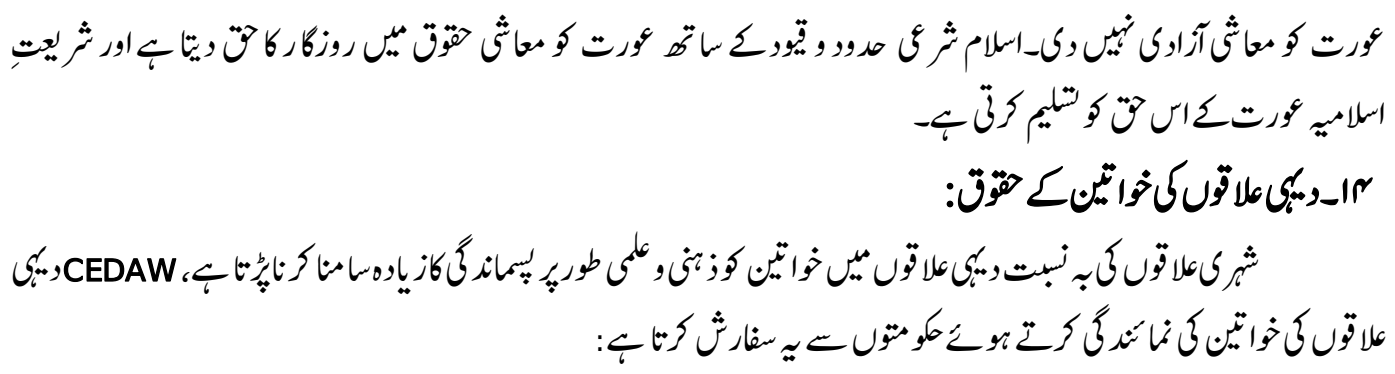

"Governments must do something about the problems of girls and women who live in rural areas and help them look after and contribute to their families and communities. Girls and women in rural areas must be supported to take part in and benefit from rural development, health care, loans, education and proper living conditions, just like boys and men do. Rural girls and women have a right to set up their own groups and associations." 1

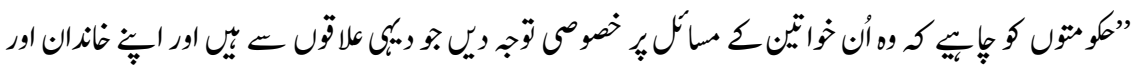

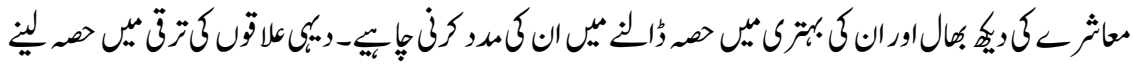

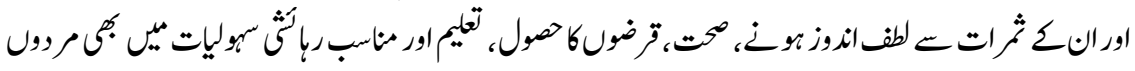

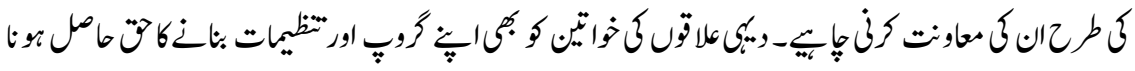

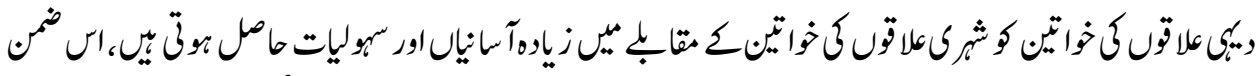

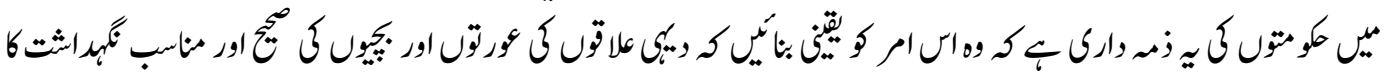

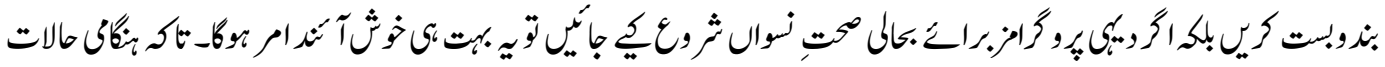

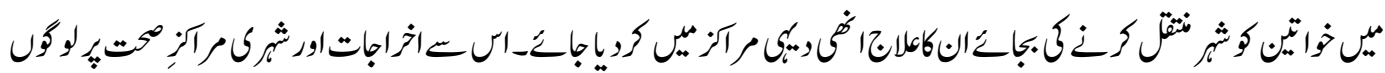

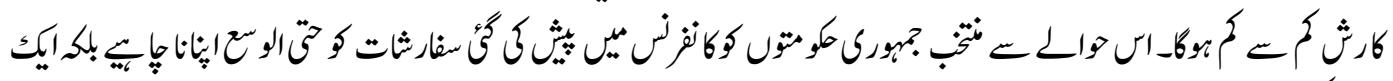

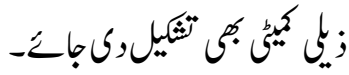

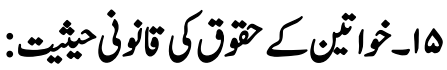

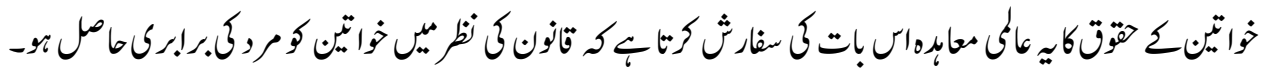

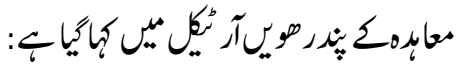

${ }^{1}$ www.un.org/womenwatch/daw/cedaw/text/econvention, (accessed July15, 2018) 
"Girls and women and boys and men are equal before the law, including laws about freedom to go where they choose, choosing where to live, signing contracts and buying and selling properties. Women have the same 'legal capacity' as men."1

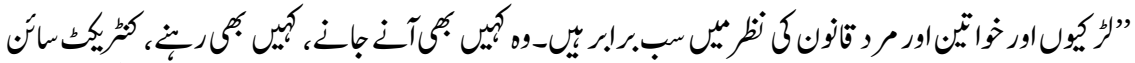

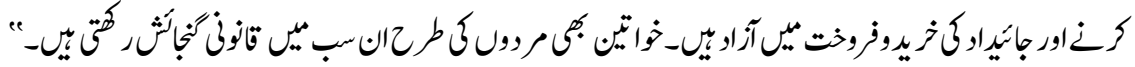

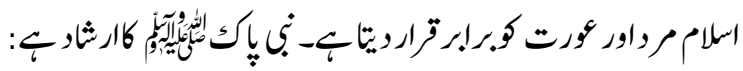

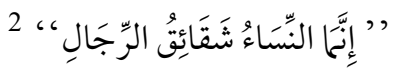

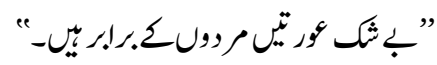

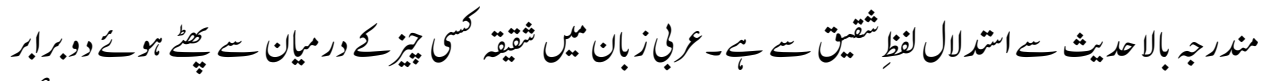

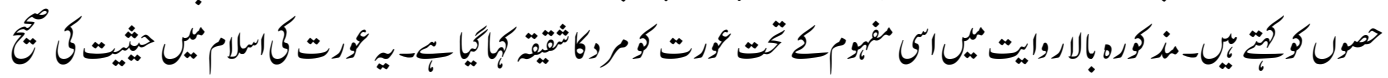

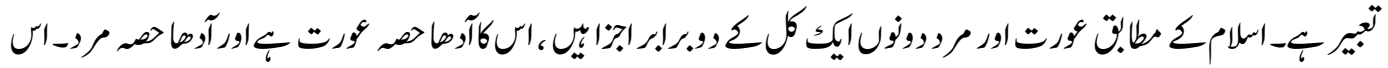

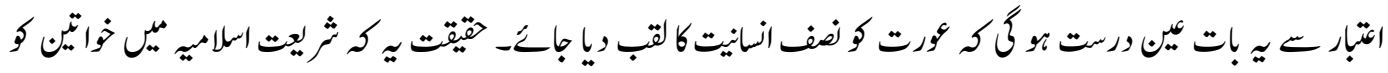

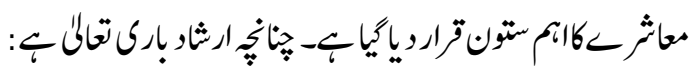

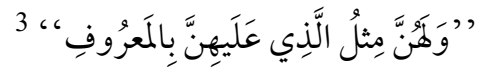

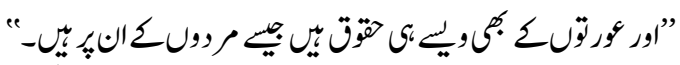

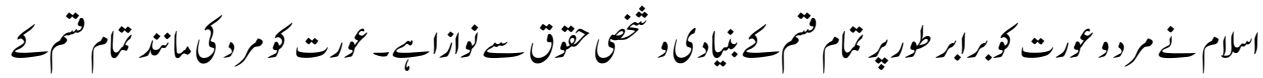

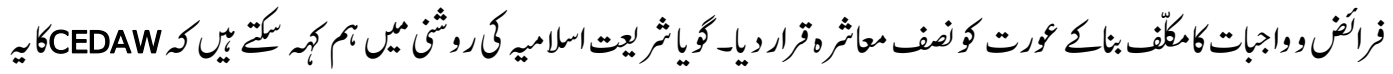

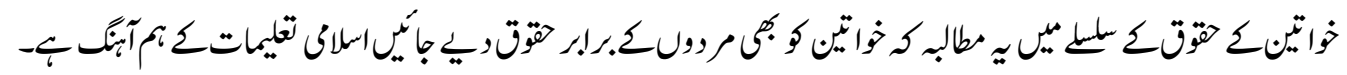

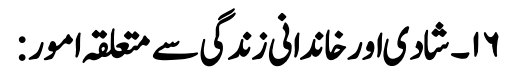

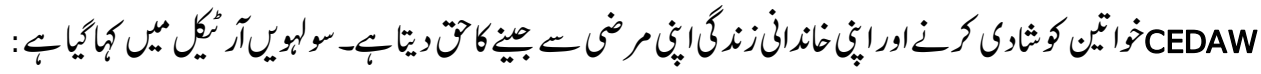

$$
\begin{aligned}
& \text { "Women have the same rights as men to choose whom they marry, } \\
& \text { the number of children they want to have and to care for them when } \\
& \text { they are born. Women also have the equal right to the property that }
\end{aligned}
$$

${ }^{1}$ www.un.org/womenwatch/daw/cedaw/text/econvention, (accessed July15, 2018)

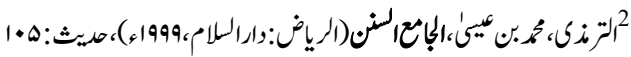

$$
\begin{aligned}
& \text { 3 البقة:HA }
\end{aligned}
$$




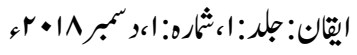

they get with their husband while they are married. To end child marriage, governments must set a lowest age for marriage and make sure this is followed. All marriages must be registered (officially recorded with the government)"1

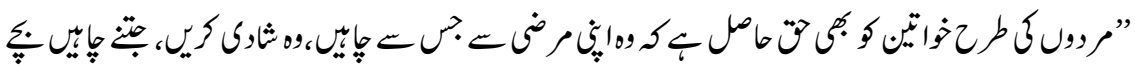

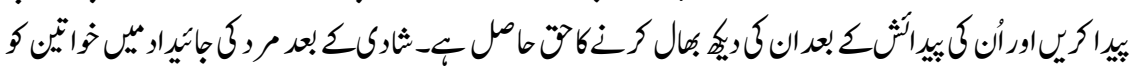

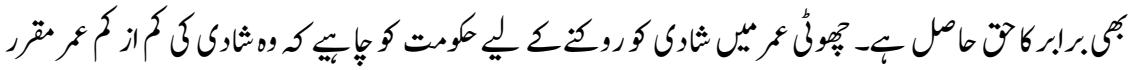

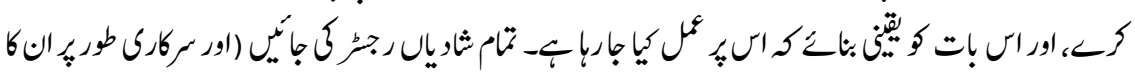

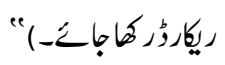

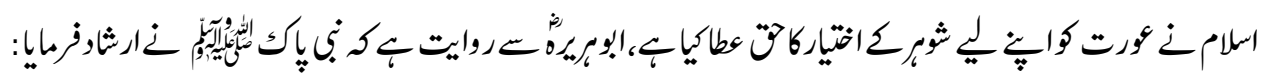

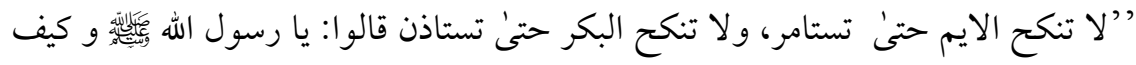
اذنها، قال: ان تسكت ،

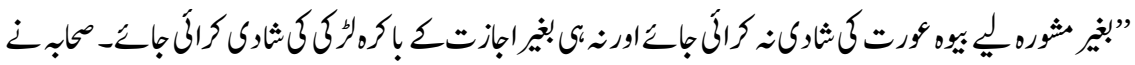

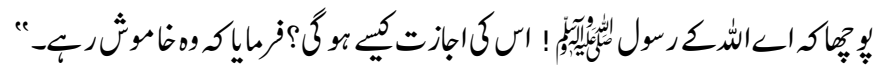

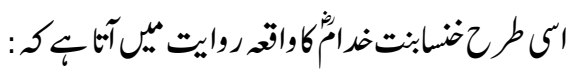

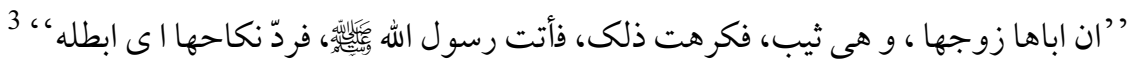

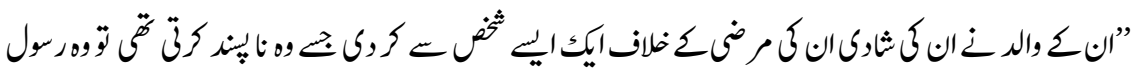

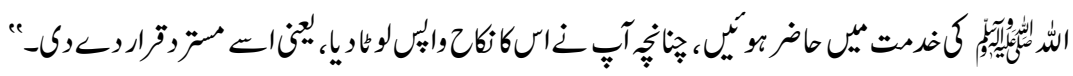

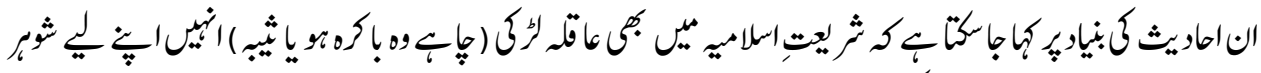

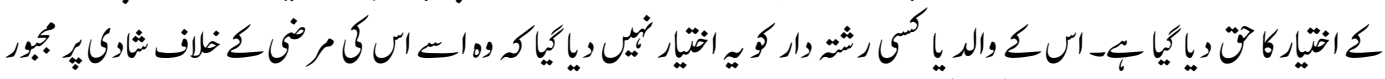

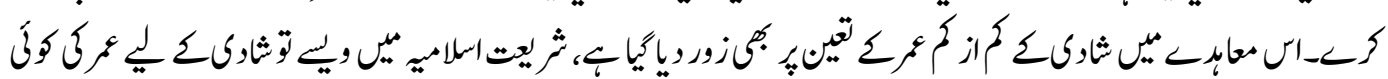

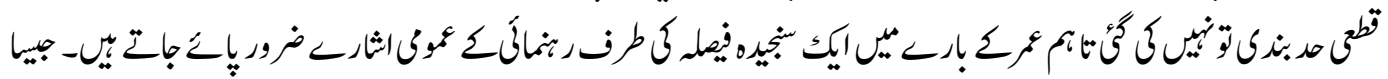

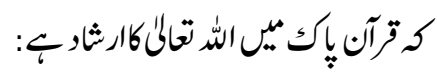

${ }^{1}$ www.un.org/womenwatch/daw/cedaw/text/econvention, (accessed July15, 2018) 


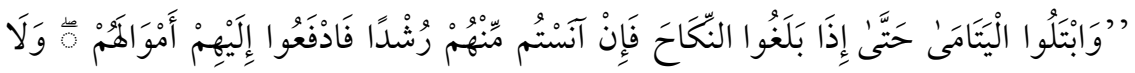

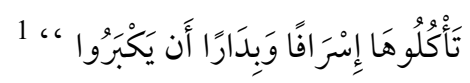

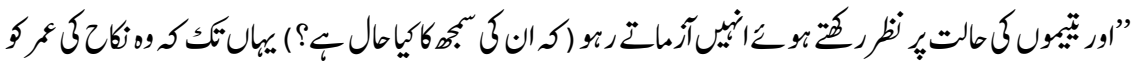

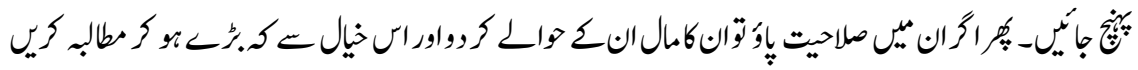

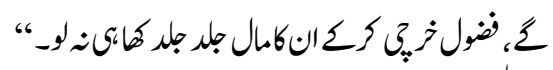

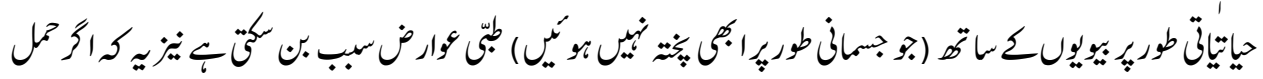

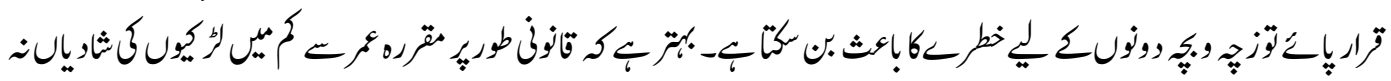

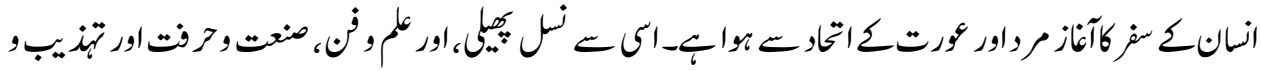

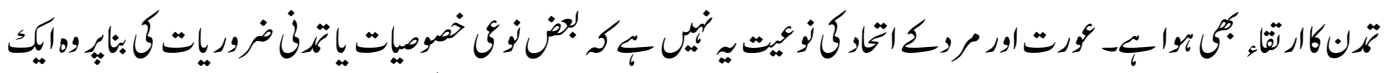

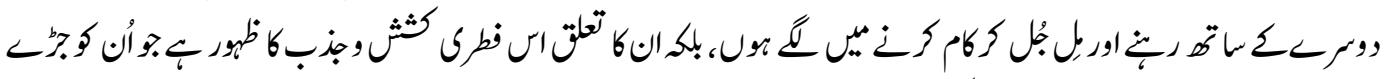

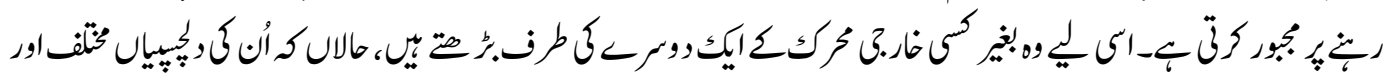

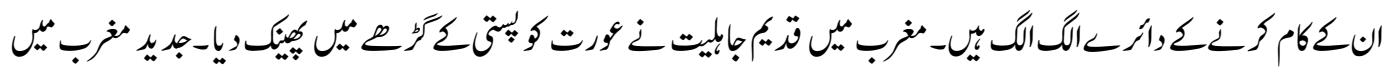

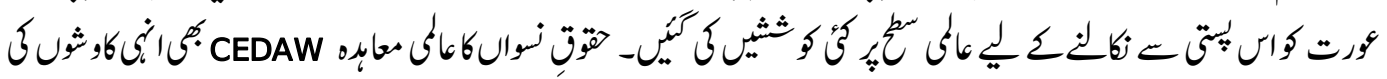

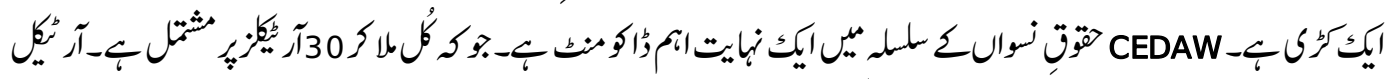

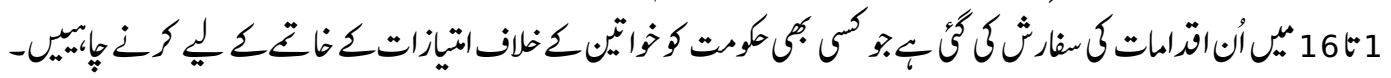

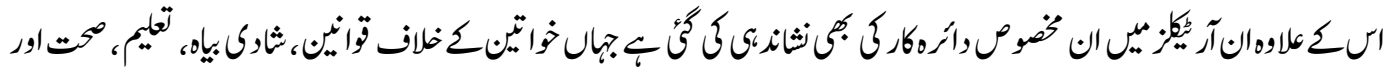

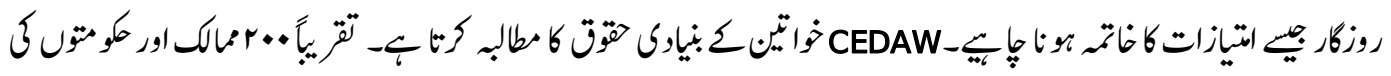

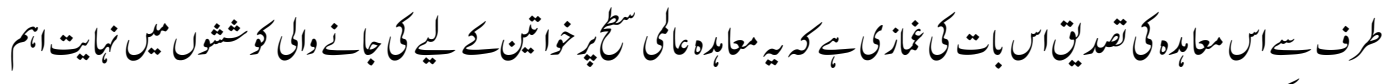
مثيت ركمبا بـ

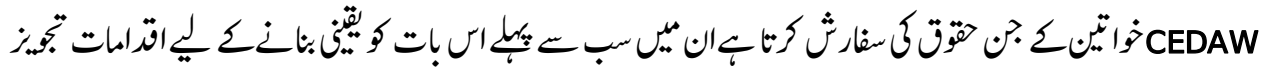

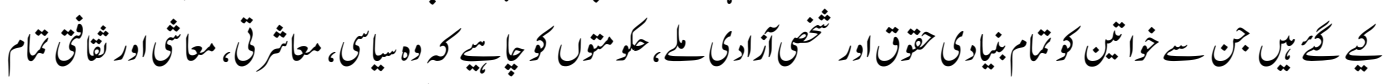

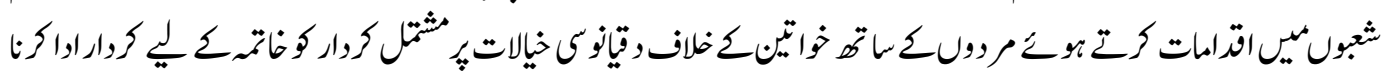




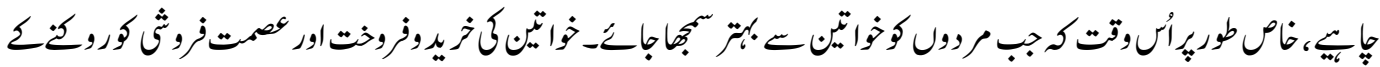

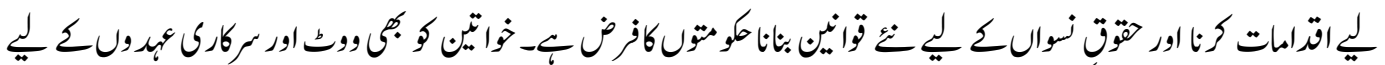

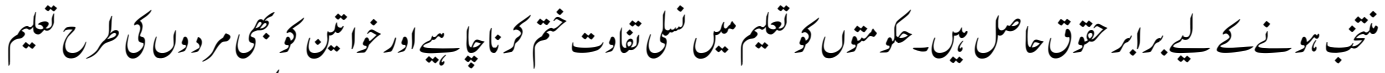

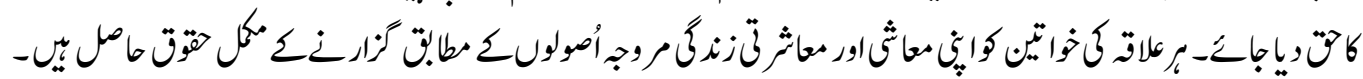

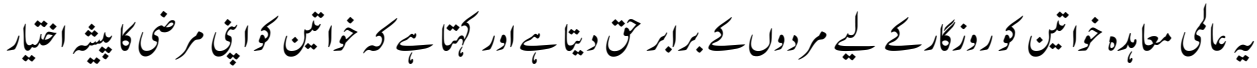

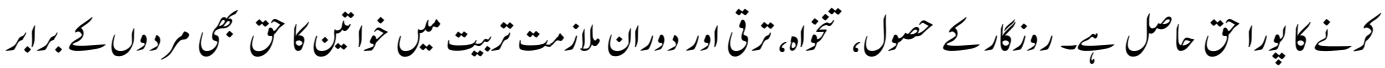

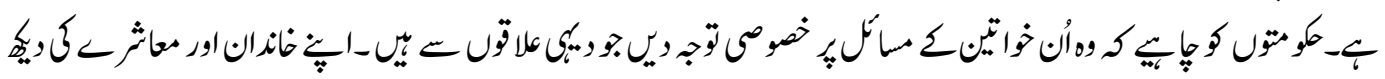

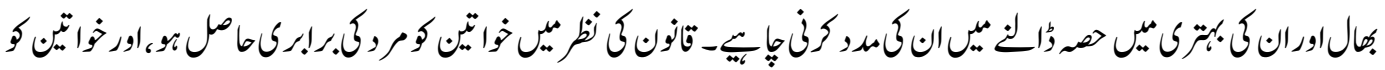

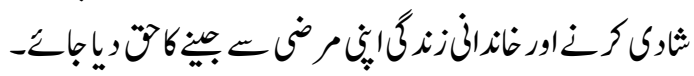

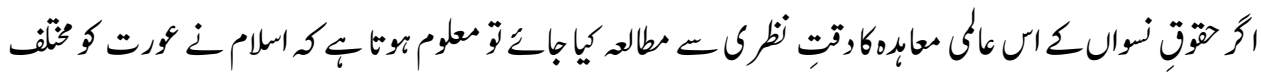

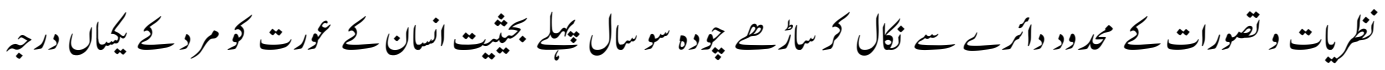

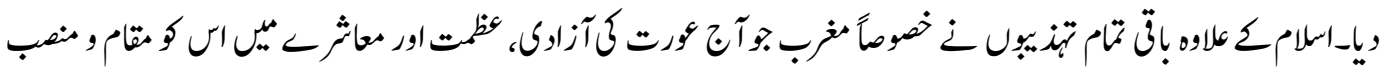

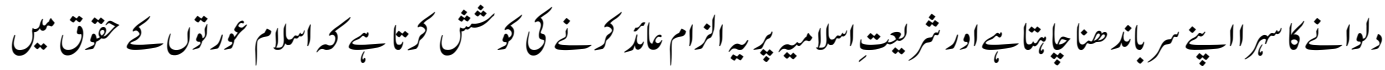

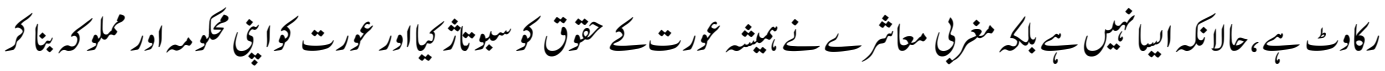

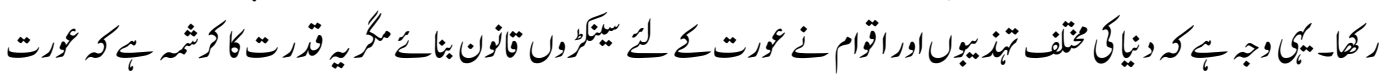

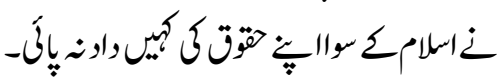

(c) (i) This work is licensed under a 